Part II - Historical and Contemporary Manifestations of the Power Dynamics in Securitization 


\section{The Legitimation of Council Rule Through Vedute of the City and Territory of Nürnberg from the Sixteenth to the Eighteenth Century: Visualizing Insecurity within an Image of Secured Order}

Katharina Krause

As a discipline, art history has often examined the function of the visual arts and architecture in expressing power and power relationships. Researchers have focused primarily on the question of how works of art were produced or called upon to represent dominance. This immediately suggests a problem: art history has not dealt deeply with social scientific theories of "power." Art historians are likelier to speak about dominance than power and to examine art as a means of stabilizing or extending dominance in the sense of institutionalized power. ${ }^{1}$ When they do speak about power - sometimes from a historical and sometimes from an anthropological perspective - they address the specific power influence of visual art and, less often, of architecture, which they distinguish from the power of texts. ${ }^{2}$

Unlike considerations of this kind, whose interest lies in the drawing of difference between images and texts or in developing a fundamental theory of the image, our focus in the following study is to analyze the use of images and architecture in political processes. We begin from the idea that images and architecture have authors who seek to direct their uses and effects in different specific situations. We are not denying the immediacy of the effect of images, as articulated in the suddenness of wonder or horror; however, we do want to point out that both images and texts transmitted in written form are received at a distance from their immediate act of expression, and are thus removed from their authors' direct control over the time,

1 Warnke 1984; Beyme 1998; Mühleisen 2005, for a cross-epochal, interdisciplinary overview, Hebel/ Wagner 2011. Münkler's paper 1995 was reviewed from the historian's perspective in Mallinckrodt 2006, among others.

2 Freedberg 1991. Most recently, the discussion on Bredekamp 2010. As an example of the mistaken reception of the book, see Paul 2013 and its review by Stiegler 2013. 
context, and mode of their reception. Thus, texts and images may have different meanings ascribed to them in different contexts that differ from their authors' intentions. Whether pictures or buildings serve to create or represent security thus depends substantially on the context of their reception.

The organization and tradition of research in art history have not completely separated the visual arts from architecture and urban construction, but these fields have developed quite differently, since the specific material contingencies of these arts are of vital importance, especially for the constitution of works. For this reason, we will look at them separately.

In relation to the proximity or distance of visual artworks from dominance, it is important to consider epochal differences in the nature of the artist's profession, which can be divided into a long-lasting phase when works of art were almost exclusively created by specific commission, followed by a phase that continues to this day when works of art are produced for a market. ${ }^{3}$ In general, art historians have shown great interest in seeking evidence that works of visual art were and are specifically created with the intent to destabilize or constrain prevailing circumstances of rule. Pictures, which could be and can be created and reproduced at relatively small expense, are especially apt to be used as a medium to visually critique the conditions of rule and express social grievances. In the premodern era, this function principally related to drawings and prints, that is, works on paper, but this was conditional upon having ready access to paper or the printing press. ${ }^{4}$ In the modern era through to the present time, printed products have been supplemented by audiovisual and so-called new media. At first glance, due to economic considerations, pictures intended for serial reproduction and broad distribution would tend toward communicating more exceptional and often threatening events. This is the case, for example, for the illustrated broadsheets of the early modern period and, to a similar degree, for modern media products, which have some-

3 Warnke 1996; Haskell 1980; Bätschmann 1997. About the self-deception of the avant-garde, it is always worth re-reading Bürger 1974. A helpful introduction to the current state of research: Locher/Markantonatos 2013.

4 For an introduction: Harms/Schilling 2008. As a case example from the perspective of journalistic studies Bellingradt 2011, Cilleßen/Reichardt 2010. For the interferences between "high" and "low" art and between affirmative and critical pictures: Hattendorff 2012. 
times been topics of study in the discipline of security studies. ${ }^{5}$ The full spectrum of how political imagery was used in the early modern period also includes techniques for assuring long-term stabilization of one's own position and for destabilizing the position of one's opponents, and these do not necessarily rely upon depicting or visually highlighting the current situation. ${ }^{6}$

In the case of architectural works and urban construction, it is rare to see any distancing from institutionalized power. Because of the longer durability of their materials and the greater costs and logistics required for their construction, buildings are regarded as being in greater proximity to ruling entities than works of visual art. This assumption has become so widely accepted as self-evident that researchers have rarely questioned the evocative power of buildings. For this reason, it is important to recall that architectural works, as constructions by those in command, not only set broad frameworks for human behavior but also shape people's behavior on a day-to-day basis: "The power of architecture lies [...] in its materialisation of what is normal or taken for granted. Buildings, insofar as they are arrangements of space designed to 'facilitate' a way of living that is 'taken for granted', are material expressions of the way the world is held to work. As such, buildings are always and immediately ideological: they seek to give a legitimation and authority to something which is arbitrary."7

In close alignment with the historical development of architecture as an artistic and technical profession, architectural historians have primarily focused on issues such as the ways that building types and the formal language of architecture represent the function of the building and the customer's rank within a group of peers or in relation to higher-ranking or lower-ranking groups. In this respect, architectural historians differentiate between the intended and actual effect on an audience that is directly and personally exposed to a building, and the intended effect on an audience to which the structures will be communicated though media - whether in text or image. ${ }^{8}$ The discipline thereby focuses on domestic and foreign policy effects of construction activities.

5 As a program of research, only in Williams 2003, pp. 524-552 For proposed theory and empirical application, see Hansen 2011.

6 Cilleßen 1997.

7 Johnson 2006, pp. 285f. referring to Anthony Giddens to justify why "vernacular architecture" also exercises power.

8 Völkel 2001, especially pp. 237-276. 
Visual works and buildings, including monumental buildings, are rarely mentioned in political discourse or political theory as objects of securitization. This may come as a surprise, given Plato's insistence on the danger to the common good of works of art in the tenth book of his Politics. However, this blind spot - which goes beyond securitization studies - is less surprising once we recall that since antiquity, along with the low estimation of image producers due to their low social status, there was also the conviction that only written texts by the educated and the learned, and not visual artworks by artisans, could be of any relevance to political practice. ${ }^{9}$

This stance converges with that of the field of art history; thus, beyond neglecting theories of power, the field has failed to take up a set of issues related to how works of visual art may create or represent security at the level of the community. However, art historians have been interested in questions of censorship - as directed against the visual media cited above. ${ }^{10}$ The themes of censorship and how image producers have responded to censorship have been discussed primarily in iconographic studies on the use of censorship as a controlling measure to maintain an existing political order - but less often in terms of studying the creation or representation of security. As measures that accompany and foster attempts to change the political order, the toppling of memorials and the storming and destruction of official architecture as well as their reconstruction have received some attention. In these cases, security and insecurity are rarely considered in terms of politically motivated iconoclasm, nor are the responses of those in power, who first turned monument preservation into a security issue by promoting their protection. ${ }^{11}$

Things are no different in the case of buildings. It is beyond question that some works of architecture are works of security architecture. The list would encompass fortresses, the fortification of cities and private buildings, and special building projects associated with public security, includ-

9 A study on the forms of dissemination of a ban on images or the destruction of images ordered by those in power would discover further reasons for the absence of this aspect; thus, images are destroyed in order to help implement a particular religious tendency - at the same time seeking to have the effect of permanently destroying the cultural identity of a portion of the population (Bamyan 2001; Palmyra 2015).

10 See. e.g. Goldstein 2012.

11 See, among others, Bildersturm in Osteuropa (1994); Gamboni 1998. There are a series of case studies in Fleckner 2011. 
ing prisons and buildings intended to protect the government and population in case of war or catastrophe, such as bunkers. However, this field also lacks systematic presentation. Accordingly, the sole touchpoint that can be offered is the view that architecture at its root is grounded in man's existential fear of the weather and of internal and external enemies. ${ }^{12}$

In the context of those gaps we have only briefly outlined above, this essay uses a case study with limited materials to inquire about the potential functions of images in the typology of security power. In consideration of the introduction to this volume, we will inquire about the role of images in processes of securitization. Our assumption is that the function of a unique image may change depending on the conditions of its reception. The same image may be differentially deployed and have different effects on processes of securitization, depending on the type of power to be securitized and the type of power employed in the securitization. ${ }^{13}$ This means that context is of central significance in the uses and impacts of images, underscoring the relevance of statements on contextual integration in the securitization model, especially as practiced by representatives of the Paris School of security studies. ${ }^{14}$ Because of the interest in the work, the notion of "context" in the field of art history includes the long-term view beyond the individual context, as well as prolonged interruptions in the use and reception of works, and thus changeable historical conditions, as well as material changes in the works themselves. ${ }^{15}$ Thus, it also makes sense that images are not merely deployable in a dramatically staged "securitizing move," as would be suggested by the viewpoint of the Copenhagen School of security studies. Only in rare cases in the early modern period is it conceivable that a situation would be securitized by means of presenting "an existential threat requiring emergency measures and justifying actors outside the normal bounds of political procedure."16

Rather, it is generally the case that situations of existential threat to a community and measures required to deal with them also tend to become apparent to the actors when they are or at least appear to be unusual and new, and the actors link them back to familiar processes of legitimiza-

12 Erben 2003/2004.

13 Langenohl, in this volume.

14 Balzacq 2005.

15 See in this regard programmatic proposals in Busch 1985 and Kemp 1993.

16 Buzan/Wæver/de Wilde 1998, pp. 23-24.. 
tion. ${ }^{17}$ Thus, the role of images can repeatedly recall security routines during a prolonged process and thus not only to hold in collective memory the context for extraordinary measures but also to legitimize them in the case of a similarly relevant state of threat. However, the role of images can also be to keep latent threats alive in an atmosphere of deepest peace and wellbeing, and thereby place the focus on a feeling of insecurity of human existence, whose mastery generally lies beyond human power. Here as well, there takes place "a classification of circumstances into a concept of order that creates meaning" - in this instance, the story of salvation oriented toward the Judgment Day. ${ }^{18}$

Thus, one could conclude that the interest in security routines, as particularly advocated in security studies by the Paris School, would be suitable for analyzing aspects of securitization in the early modern period. ${ }^{19}$ However, these approaches also focus on innovations. In 1998, Buzan, Wæver and de Wilde proposed, without further exploration, that in cases of extreme threat and natural catastrophes, "the need for drama in establishing securitization falls away, because it is implicitly assumed that when we talk of this issue we are by definition in the area of emergency." 20

The pool of images of the Free Imperial City of Nürnberg examined in this chapter shows among other things that the production and reception of images takes place among a set of actors who have varying claims of interpretive authority about security-related image content. Despite the huge difference in the pace and scope of image production and dissemination in the early modern period compared to the present time, we can confirm a secondary aspect of the conclusions offered by Hansen, who saw images performing very specific functions. Hansen states that "the possibility of circulation through modern media technologies challenges securitization theory's rather traditional notion of securitizing actors as political elites." In fact, this process of circulation had already begun with the production of images in the artistic centers of the sixteenth to eighteenth centuries. So long as we do not limit categorization of images to a specific "securitizing move" but rather view them as setting the context for such a move through the creation of a consciousness of permanent threat, we can see an ever-

17 Kampmann/Krems/Krause/Tischer 2012.

18 Schnadenberger 2016, especially p. 74.

19 Bigo 2002, p. 73.

20 Buzan/Wæver/de Wilde 1998, pp. 27-28. 
expanding number of actors from different social groups come into play in the early modern period. ${ }^{21}$

Given the state of the research outlined above, this is not the place to develop a comprehensive typology of images and their use in securitization processes. Our aim will be more limited. We will ask: (1) Over the long run, how does a dominant political and social order with a specific cast of actors employ images of the city and its surroundings as the basis for affirming the security of an early modern political system, even while using signals of latent threats to depict that system as perpetually endangered?; (2) What is the role of contexts of image reception, predicated on the memory of events as well as transmitted knowledge of aesthetic conventions and modes for presenting image and textual genres - and how do these elements come together to generate the anticipated efficacy of the images?; and (3) Can elucidating the role played by images in creating and depicting security in the securitization process help us understand those features specific to early modern image production?

\section{Rule over the city and its environs}

As a case example, we will use depictions of the Free Imperial City of Nürnberg and its environs in prints and image series from the Protestant Reformation to the end of the eighteenth century. The outpouring of Nürnberg pictures began in the sixteenth century and stands at the apex of quantity and quality, even when compared to large European states and centers of picture production..$^{22}$ In some cases, these vedute were produced for large compendia of European cities and countries, or at least integrated into them. In their surfeit, however, they appear to have been independent publishing works that were sold by their engravers and publishers. They were created at the initiative of these producers and were only rarely subsidized by the Nürnberg Council, but, like all printed works of the early

21 Hansen 2011, p. 57, McDonald 2008, p. 573, and Guzzini 2011, p. 335, emphasize the procedural character of securitizations and the necessity of embedding them in a specific context.

22 The Nürnberg vedute production has not been researched in its totality. The most comprehensive work remains that of Müller 1791. For an introduction, see Mende 1999. For an overview of the history of the city, see the essays in Pfeiffer 1971. Regarding the techniques for managing the potential for religious conflict, see Riegg 2004. 
modern period, they were subject to censorship. Their economic success is evidenced by the fact that they continued to be disseminated in multiple editions through the end of the eighteenth century. Thus, we have included images for the case study that would not have been associated at first glance to political events in Nürnberg. To illustrate the specific nature of the selected images, we should briefly outline the Council's communication strategy. It employed an image program that illustrated or constituted a building or festive program for the city: The Nürnberg Town Hall - enlarged after 1616 - highlights the city's connection to the Holy Roman Empire and adds to the décor from Dürer's time a series of emblems intended to instruct the viewer in the basic principles of good governance. The emblems were made accessible through the publication of a book that reproduced the images with their Latin text translated into vernacular German, and explained their meanings. ${ }^{23}$ The Emperor's ceremonial entrances were celebrated with expensive ephemeral installations; for a while, they were accessible to all interested persons and accompanied by printed explanations that were sometimes preserved permanently. ${ }^{24}$ Generally, the Council's communications of this kind about political circumstances were triggered by a specific event, but they were usually intended to generate statements with lasting effects, whether they be more normatively intended or more with a view toward commemoration. Consequently, on the part of the Council, events were primarily communicated and memorialized using the medium of medals, which as a result of the manufacturing process involved were not suitable for addressing highly current issues. ${ }^{25}$ More expeditious media included broadsheets, sometimes illustrated, and written or printed newspapers. The Council did not actively use these media but tolerated them, especially when communication of an event was

23 Emblemata Politica. In aula magna Curiae Noribergensis depicta, quae sacra Virtutum suggerunt Monita Prudenter administrandi Fortiterque defendendi Rempublicam, Nürnberg 1617, Edition Nürnberg 1640: http://gdz.sub.unigoettingen.de/dms/load/img/?PPN=PPN807277312\&DM-

$\mathrm{DID}=\&$ LOGID=LOG_0001\&PHYSID=PHYS_0004 The engravings were made by Peter Isselburg, who dedicated the volume to the Council. About the city hall as such, see Mende 1979; Schauerte 2013.

24 For example, the Entrance of Emperor Charles V. 1541 (Philipp 2011).

25 See Fischer/ Maué 2014, with numerous examples. 
linked to an overarching ethical message. ${ }^{26}$ The Council's communication practices, unless they were matters of every-day importance to the city, ${ }^{27}$ were directed more toward commemoration and the ethical interpretation of events rather than their immediate news value. Regularly recurrent processes - such as Council elections - did take place but were not made the objects of written or pictorial news stories. ${ }^{28}$ The serene quality of the Council's communication behavior was a confirmation of its competency and was thus a not insignificant contribution to the legitimation of its rule.

The vedute of a well-ordered city and its secured territory also form part of a long-term discussion on the basic facts of a well-functioning community. This theme began brilliantly with the frescos of Ambrogio Lorenzetti (1338-39) in Siena's Palazzo Pubblico. In the case of Nürnberg (and other Imperial cities) it gradually became separated from its connection to the town hall as the locus of rule and thereby also gained a broader audience. ${ }^{29}$ While in Siena, "Securitas" dominated the environs as a messenger of good and proper government; ${ }^{30}$ she was not specifically represented as an allegory in Nürnberg. Seen as a whole, the prints, which were widely disseminated in large numbers over the next 200 years, present the eye with the image of a permanently well-ordered city and its territories under municipal council rule whose inhabitants and visitors can all safely pursue their various daily activities.

26 For broadsheets, see the edition by Harms 1980; Schilling 1990, especially ch. 2 , pp. $91 \mathrm{ff}$. For the Nürnberg newspaper business, see Sporhan-Krempel 1968 (with reprints of news stories) and Zimmermann 1930. For a good overview of the research status, see Bellingradt 2011, pp. 17f.

27 For this purpose, the Council employed, among others, written decrees, which were displayed in the city. An overview of the themes and forms of these mandates, which were printed in octavo format, that is, in small format and at low cost, can be found in the digital holdings of the Austrian National Library, Vienna (over 200 examples).

28 For pre-Reformation Nürnberg, the situation is outlined in Groebner 1994; more generally, as characteristic of the epoch, see Schlögl 2014, especially the chapter on Communication, pp. 29-47.

29 For an overview of the research on Siena, see Schmidt 2003, pp. 84-135. Pictures of the territory are often found in the mansions of the princes. There is a good overview in Eser 2014. In the Netherlands, vedute were commissioned for city halls. Worthy of note is the monumental view of The Hague by Jan van Goyen, around 1650-51, painted on commission by the Mayor for the city hall (Suchtelen/ Whelock 2009, No. 20, pp. 116f.).

30 On the territorial dimension of "Securitas" at the boundary between city and country, see Skinner 1999, pp. 1-28 and Schenk 2010. 
The Free Imperial City of Nürnberg could boast that within living memory, until its opening to the troops of Friedrich II of Prussia in 1762, it had not tolerated any external enemy within its walls. This fact is conveyed and acknowledged in the writings of the period. Despite the implementation of the Protestant Reformation, the city remained custodian of the imperial insignia of the Holy Roman Empire and insisted on its loyalty to the Imperial house. Under the ruling monopoly of a small number of patrician families who made up the leadership of the city and belonged to the nobility, ${ }^{31}$ Nürnberg's oligarchy is an example of the "authoritarian type of power," and it was under constant pressure to legitimize itself internally and externally given the presence in its immediate proximity of other types of rule. ${ }^{32}$ We will only briefly outline the conditions under which the Nürnberg Council ruled. ${ }^{33}$ Externally, the Council's rule was threatened by the competing model of the sovereign princely state (Fürstenstaat). Near Nürnberg, this form of government was manifested by its closest neighbor, the Margravate of Ansbach-Bayreuth, which almost completely encircled the territory of Nürnberg. Eventful instances of real existential threat to the community and continual reminders of the need for security routines included the memory of two Margrave wars, during which the Nürnberg area was ransacked, concerning the country estates of prominent council-eligible families, ${ }^{34}$ the damages caused by siege and military marches through its territory during the Thirty Years' War and War of the Spanish Succession, as well as the repeated claims to the environs of Nürnberg extending right up to the city walls ${ }^{35}$ filed at the Imperial Court following the Peace of Westphalia. Within the city there was pressure to legitimize the oligarchy through competent action, especially in crisis situations, by maintaining rules of procedures such as municipal elections and through the manifestation of rituals, such as the oath of citizenship. ${ }^{36}$ For its part, the citizenry was not socially homogeneous, but divided into two major groups, on the one hand, long-distance traders, and

31 Hofmann 1965; Fleischmann 2008.

32 Authoritarian power type according to Popitz 1992, pp. 27-31.

33 When we speak in what follows about the "Council," we are always referring to the "Small Council" that constituted the top level of the city government.

34 We are unable to present here the dynastic differentiation of the Margraves or the events of the wars of 1449-1453 and 1552-1554.

35 Evidence from Willax 1979, pp. $203 \mathrm{ff}$.; see also Rutz 2014.

36 On the "affirmation function" of such acts as symbolic communication with the example of the Nürnberg Council election, see Rogge 2004, pp. 396ff. 
on the other, craftsmen producing for the local and regional market, and these groups pursued very different interests. The merchants and traders experienced the decades of the Thirty Years' War and the economic consequences of catastrophic municipal indebtedness as a permanent crisis, and their resentment manifested in attacks on Council rule. ${ }^{37}$

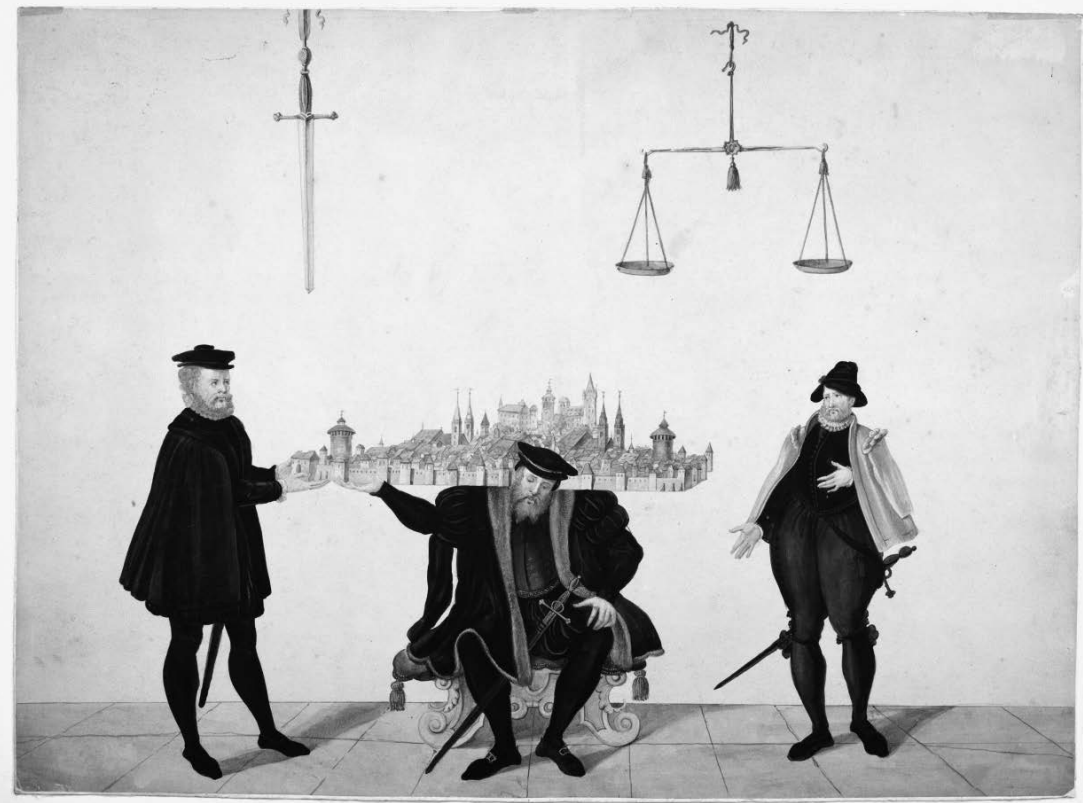

Fig. 1: The three Aldermen of the City of Nürnberg (Nürnberg, Stadtbibliothek, Abteilung Sammlungen)

The Council rulers' self-understanding was expressed in the form of allegorical representations: the eldest and most venerable of the three Aldermen sits on a golden stool with red cushions, weighed down by the burdens of the city which rest on his shoulders like a model with the imperial castle at its apex - surely not by coincidence, as it is a traditional symbol

37 Using the example of Lübeck, Hoffmann-Rehnitz (2016) indicates a similar constellation. Despite the perception of "decline" and the development of narratives to that effect, in Lübeck as well, one can document the maintenance of continuity and demand to act according to time-honored rules, rather than postulating discontinuity in the modern mode of crisis or upheaval. 
of dominance. Helping to bear the burden is the second Losunger, entrusted along with the eldest with the rights and duties of managing municipal finances. This diumvirate of the most powerful Nürnberg gentlemen seated under the symbol of "Justice" is attended by a third party representing the artisans. ${ }^{38}$ The leitmotiv of the symbol chosen by the Council to present its self-affirmation and legitimation before the citizenry is not the exercise of power, but instead the bearing of the burden of city government under the dominion of justice. The vedute of the city and its environs that we examine more closely in the following confirm this view of shared leadership. There are multiple depictions of aspects of rule as well as external and internal security, but they are somewhat parenthetical. The Councilors are not pictured among the figures populating the vedute; the street is not their place. However, the Council families are represented and kept in mind by the fact that their houses are cited by name in the legends of the prints. Of course, this is also the case for other major city attractions, such as hospitals and taverns. The forces of law enforcement under the Council's authority are certainly visible, ${ }^{39}$ but you have to search long and hard to find any Stadtknechte [policemen] in the pictures. More visible is the technical equipment for protection in case of crisis, which is shown as inactive, but well maintained. In addition to defensive chain barriers [Kettenstöcke] for blocking off the most important streets, precautions are taken against the perils of fire and the fortifications themselves.

There are scarcely any vedute that fail to include an image of a tower as part of the city fortifications - the omnipresence of the towers in the images shows the high priority of such defenses against external danger for the order of the community within. The pictures thus constitute a perfect example of Münkler's "visualization of the power of the expertocracy": the extreme secrecy about the Council's decision-making processes, the "utter invisibility of power," is contrasted with its "visualization as order." 40 What does not match Münkler's simple typology is that the pic-

38 Nürnberg, Municipal Library, Collections Department. See Fischer/Maué 2014, p. 25 (color fig.). An eighteenth century copy in the Germanic National Museum Nürnberg includes explanatory captions, which contrast the destruction of Rome and Troy as a result of vices with good Council rule (Smith 2008, p. 32, also in connection with the medals minted on commission of the Council by Valentin Maler, 1586, 1589 and 1590 (Fischer/Maué 2014, Nos. 28, 29, 32f., pp. 50-54; Tipton 1996, pp. 118-120.

39 See Bendlage 2003 for number, duties and garments.

40 Münkler 1995, p. 214. 
tures were not actually commissioned by the magistracy; rather, engravers and publishers had developed an appellative structure through a complex process of production and dissemination, which by the end of the period we are examining here, became commemorative of past greatness. This was certainly true for the castle, which had long since lost its military significance. As the seat of a distant Emperor who only rarely traveled to Nürnberg, the castle is the guarantor and symbol for the sovereignty of the totality of the city, and for this reason, in the late reprints of the engravings, which become a kind of walking tour of the city, the castle is placed at the very beginning of the series.

Internal security through external security - The ruling Council's image of Nürnberg

In 1577 the Council undertook a comprehensive review of the status of its Landwehr, a set of surrounding earth walls constructed in front of the city walls in 1449, which encircled the suburbs and many noble estates. From the inside to its periphery, the fortification system of the city was comprised of a total of five fortified rings. The castle walls represented the first ring, and the inner and outer city walls were the third and fourth. The fifth ring included the fortified cities and fortresses in other parts of the territory - outside of the Landwehr. Its military importance was thought to have been superseded by the entrenchments from the Thirty Years' War, but it was still recorded on all maps as a distinctive boundary until the city's transition to Bavaria in 1806. ${ }^{41}$

To safeguard knowledge about these fortifications, the Council commissioned the painter Paulus Reinhart to prepare a "Mappa." 42 By contrast to what might have been expected, this was not a true-to-scale map intended to enable the military to detect violations by negligent property owners, but instead a bird's eye vista of Nürnberg's environs. Proceeding out from the city walls, it presented the land and the people in a circle around the city within a hilly landscape, where the to and fro of the trenches and

41 Willax 1979.

42 The map, which represents an official map in legal and administrative act by the authorities, has been preserved in the Nürnberg State Archive. See Timann 1987, p. 196; Timann 1993, pp. 121-139. Doosry 2014, pp. 113-125; see Schiermeier 2006 for evidence of all known city maps of Nürnberg during this time period. 
walls of the military defenses appeared as only one boundary among others, together with the many fences enclosing the meadows and fields. The map was hung in the war room of the City Hall and kept hidden behind a curtain. In this way, it was accessible in case of need but kept secret.

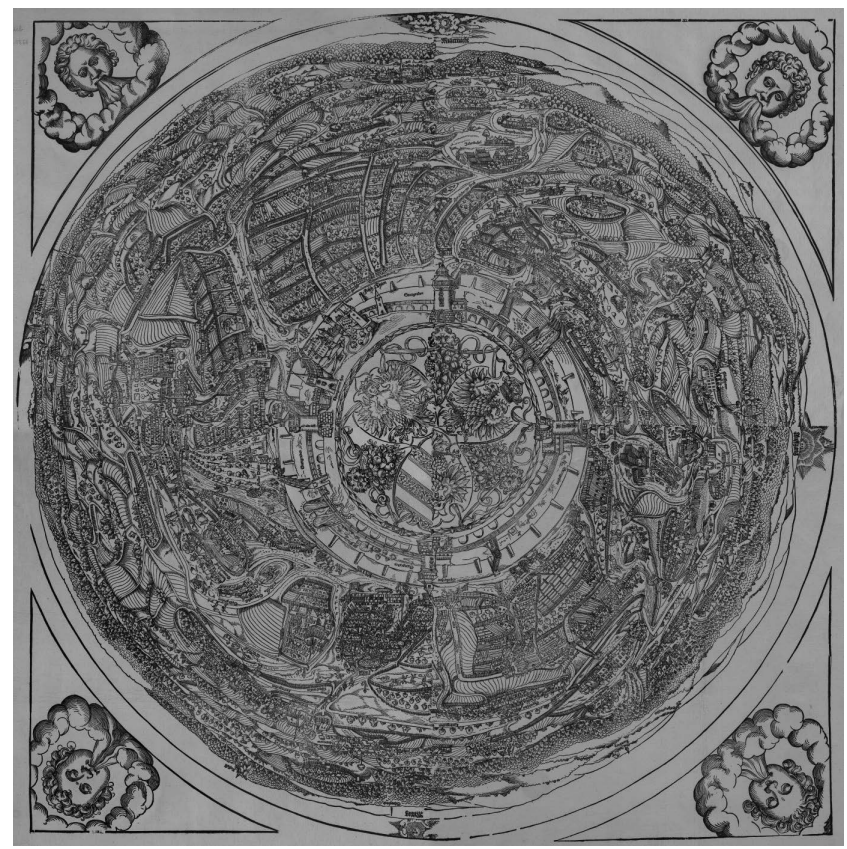

Fig. 2: Stephan Gansöder: Nürnberg, birds-eye view of city and surroundings, woodcut on four pages (Munich, Bayerische Staatsbibliothek)

In 1577, when Stephan Gansöder offered to duplicate the map in woodcuts, the Council did accept his offer, but set up the printing press for creating the prints in the Town Hall under its direct control. From this one can surmise that the recipients of the first edition of 17 copies of this large-scale map printed from four blocks were carefully chosen. The printed "Mappa" thus remained exclusive, if not quite as secret, in accordance with the Council's wishes. ${ }^{43}$ Ultimately, the map held no secrets concerning military defenses, for although it was based on an exact description of

43 At this point, we do not have statement from Council documents, nor are any traces to be found of the distribution of the printed maps. In general, the literature 
the Landwehr, the map did not reproduce it using modern surveying techniques. However, as a joint effort by Reinhart (a draftsman) and Gansöder (a wood engraver), the work did exemplify Nürnberg's artistic and technical achievements: ever since Emperor Maximilian's major commissions to Dürer and the artists and artisans associated with him, the creation of giant woodcuts intended for display on a wall - that is, images printed from multiple wood blocks - had been a tour de force of the Nürnberg arts. ${ }^{44}$

From 1529-30, the Council sponsored another Nürnberg wood engraver and publisher, Nikolaus Meldemann, through loans and privileges to create and publish an all-around view of the city of Vienna during its besiegement by the Turks. Therefore, Meldemann dedicated his presentation of the Turkish siege of Vienna to the Nürnberg Council and explained his form of presentation not only on the woodcut itself, but also in a separately published accompanying text, which - topically - in the service of praising the city, as a description of Reinhart's and Gansöder's later work suggests: "[...] when one stand in the midst of a city/on a high tower/and looks around over the entire city/into the landscape (the same into the city), then one sees villages/castles/waters/forests mountains and valleys etc./and whatever is in the whole landscape (that is visible) that lie surrounding the same city/and so he can see all around the city/and not much is going to remain concealed." 45 Moreover, Meldemann stresses that his presentation format, which refrained from showing the details inside the ring of walls, was also intended to keep the costs low enough that the work would remain affordable "for the common man."

The different occasions and motivations for the two works make clear why the focus was particularly an internal one. Reinhart and Gansöder

assumes that the prints of the "Mappa" were also intended to be kept secret but this is not proven by sources. The Council members may have been the recipients, in this regard, see the vedute by Lautensack/Sautter (n. 57).

44 The "Ehrenpforte" [Triumphal Arch] and the "Triumphzug Kaiser Maximilians" [Emperor Maximilian's Triumphal Procession] were, among others, part of the original décor of the Nürnberg City Hall. See Schauerte 2001; Warncke 2013.

45 Meldemann 1530, as cited in: http://data.onb.ac.at/ABO/\%2BZ16901070X. See Düriegl 1980: ,[...] wann einer mitten in einer stat/auff einem hohen thuern stuende/vnd kuende vber die gantz stat/gerings umb/inn ein landschafft hinein sehen (des geleychen in die stat hinumb) so sihet der Doerffer/Schloesser/wasser/veld berg und thal etc./und was in der gantzen landschafft (so anderst sichtig ist) umb dieselb stat herummen ligt/und so er untersich in die stat herab sihet/mag im auch nicht viel verporgens bleyben/“". 
contrast the image of the event of the (successfully repelled) Turkish attack on the Imperial City of Vienna and the devastation of the surrounding countryside by siege and troop movements with a depiction of the totally peaceful and prosperous territory of the fortified, Imperial City of Nürnberg, loyal to the Emperor. In 1577, this is clearly an imaginary picture; the patricians' country estates amidst the fertile landscape crisscrossed by well-traveled roadways were yet to be fully restored after the plundering of the Second Margrave War, and, in general, "vigilance" was still a central theme in the political iconography of the city. As Nürnberg's elite, the Council had given a prominent place to the environs in the work as a contrasting image to recently experienced and always threatening danger.

\section{Pastoral ambivalence - The cultural elite's image of Nürnberg}

Since the waning days of the fifteenth century, Nürnberg had been an extraordinary place for the production and sales of city views. The city's self-image was molded by the 1493 world chronicle that was written by Hartmann Schedel and published by Anton Koberger; it is a city with many towers, dominated by its two principal parish churches with the imperial castle at its apex, further demarcated from the surrounding lands by multi-turreted walls, with scattered suburbs, where the gallows provide evidence of the city's claim to legal authority, and thus its dominion over the environs. ${ }^{46}$ We can assume that with artists in Nürnberg such as Wolgemut and his pupil Dürer, their pupils and members of their workshops, there was a tradition of producing city and landscape images that also aroused interest in a local audience. Thus, it comes as no surprise that landscape artists - painters as well as copperplate engravers - earned their livelihood in this primarily Lutheran imperial city, many of them having come to Germany from the Netherlands since the late sixteenth century either as religious refugees or for economic reasons. ${ }^{47}$ Thus, Nürnberg was able not only to import new artistic accomplishments but also to produce them in the city and adapt them to its own needs.

These innovations also include the first print series with views of the Nürnberg environs. Only 10 years after the first Dutch examples, which

46 See Mende 1999; Meyer 2009, pp. 294f.

47 For an overview, see Pilz 1952. 
elevated the unspectacular surroundings of Haarlem into evidence of its newly achieved sovereignty as a theme of print series, artists began to draw motifs from the environs of Nürnberg in the mode of vedute. There were several existing templates for reproducing the Nürnberg landscape, and artists drew on Dutch series, such as the "Plaisante Plaetsen" by Claesz Vischer (1611-12), and his replicas of the Brabant "Small Landscapes" by Pieter Brueghel the Elder (1612). ${ }^{48}$ The original drawings for the series of engravings were by Jan Brueghel the Younger, who had spent some days in Nürnberg. From the pool of sheets, the engraver and publisher Peter Isselburg, originally from Cologne, selected a total of six images, which he kept in a similar format to form a self-contained series. The execution of the prints is ascribed to Matthäus Merian the Elder. ${ }^{49}$

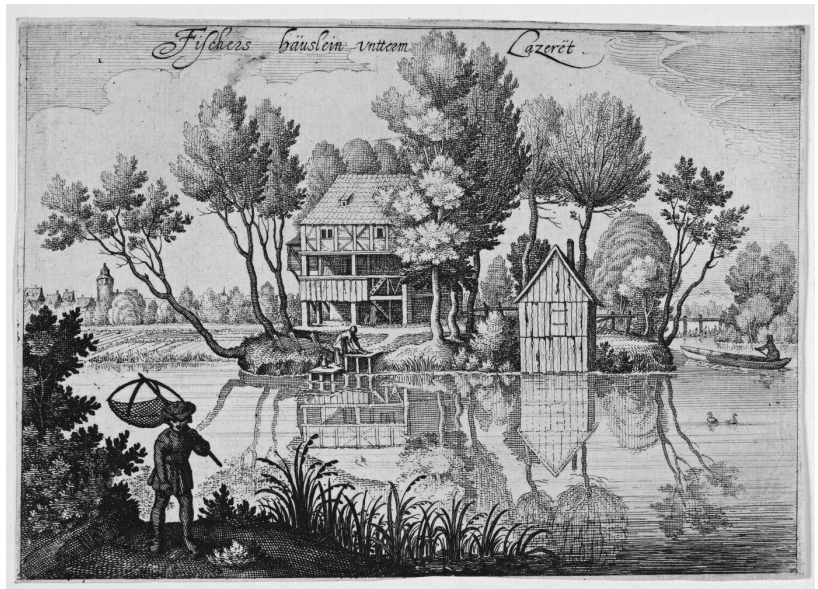

Fig. 3: Jan Brueghel the Younger (draughtsman)/Peter Isselburg (publisher): Das Angersche Weiherhaus [The pond house of the Angerer family] (Braunschweig, Herzog Anton Ulrich-Museum)

48 For a good overview of the state of research, see Gibson 2000, pp. 27-49, 85-116.

49 Van Camp (2013) has classified 11 drawings as part of the series. Two drawings were most likely etched by Jan Brueghel himself. The examples used were from the Herzog Anton Ulrich Museum, in reproductions from the Virtuelles Kupferstichkabinett, http:/www.virtuelles-kupferstichkabinett.de/index.php? selTab=3\&currentWerk=13422\&. See also Schmidt 2000, pp. 132f., still with attribution to Jan Brueghel the Elder. 
This image features the Weiherhaus [pond house] of the Angerer family, which had been previously depicted by Dürer. ${ }^{50}$ The engraving shows the timbered house on a wooded island next to a pond whose smooth water surface reflects the buildings and the vegetation. In the distance, we see one of Nürnberg's gate towers; the background is formed by a fisherman with a net, and a barge on its way to the island. The themes are the modest buildings themselves, the reflections in the water, the ambience of the cloudy sky, and the people who are going about their work. The caption on the page emphasizes that this is a depiction of a real place.

The print pays tribute to a work by Dürer, the city's most famous artist, whose works were already much sought after in the decades around 1600 - but at the same time, cityscapes such as these reflected a more recent movement in the European market that focused interest on local environments. This new mode was also characterized by the accurate reproduction of the buildings embedded in their surroundings and collections of farmsteads and rural roadways, which were all identifiable real-world places furthermore, the inscriptions reveal they were meant to be identified. The primary focus of the depictions are the patrician country estates, but they also typically include fishery, gardening, and agriculture, the leper's hospital as a patrician charity, and Mögeldorf with its mansions and inns, a favored destination for excursions from the city. Very often, one sees one of Nürnberg's gate towers in the distance, thereby maintaining the connection to the imperial city. Moving about in these landscapes are farmers, fishermen, shepherds, travelers, pilgrims, and idlers, pigs, sheep, cattle, and horses. A new feature in comparison to Dürer's famous watercolors is that these images, as in the Dutch works, were now compiled into series and sold as separate pictures. As in the 1577 round woodcut, these works exude a basic aura of well-being - a sense of contentment that is ensured by the patricians in their country estates and which now extends explicitly into the pastoral landscape. ${ }^{51}$

50 Regarding the building, see Giersch/Schlunk/von Haller 2007 (http://www.herrensitze.com/st-johannis-i.html); the unit was owned by the Angerer family, and was presumably destroyed in the course of 1631 work on fortifications. Dürer drew the Weiherhaus [pond house] in a watercolor now at the British Museum in London. He used the watercolor for his 1498 copperplate of the "Madonna with the Monkey”. (Schröder/Sternath 2003, No. 30f, pp. 182-185).

51 There are parallels to the presentations of the environs of Nürnberg from Schwalbach by Anton Mirou and Matthäus Merian the Elder (Diefenbacher 2002) and from Strasbourg by Wenzel Hollar (Pennington 1982, No. 754-756). 
Nürnberg's environs also appear as a pastoral landscape in the 1644 "Pegnesischen Schäfergedicht in den Berinorgische Gefilden," jointly published by Sigmund von Birken, Philipp Harsdörfer, and Johann Klaj as the first printed work by the literary society they had founded called the Pegnesische Blumenorden [Pegnesian Order of Flowers]. ${ }^{52}$

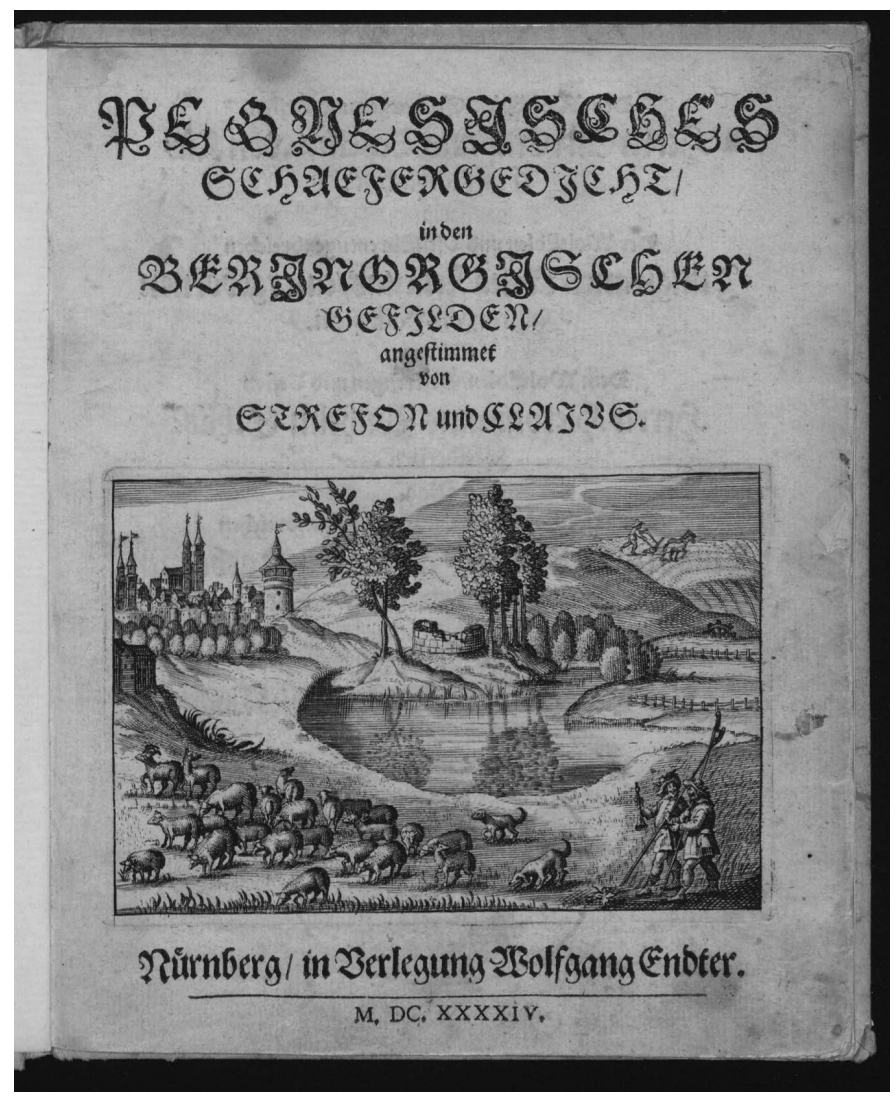

Fig. 4: Pegnesisches Schäfergedicht, [Pegnesian Shepherd's Poem], Title Page (Wolfgang Endter, Publisher) (Göttingen, Staats- und Universitätsbibliothek)

52 Harsdörffer/von Birken/Klaj 1644. For the literary devices and standing of Nürnberg's baroque poetry, especially about the meaning of oral and sung speech, see Garber 2009, pp. 43-58; Garber 1995, pp. 146-154. 
The document's title page presents all the elements familiar from the older vedute: the silhouette of the city with its two parish churches and one of the broad towers, the surface of a body of water, enclosed pastures and a farmer ploughing his field. Thus, it is a locus amoenus, where two shepherds, Strefon (Harsdörfer) and Clajus (Klaj), are grazing their sheep and striking up their melodies. The scene - the depiction is of the meeting place of the Order of Flowers west of the city - is thus specifically attuned to the text but thereby becomes ambiguous. The ruins of a building testify to the age of the city; a mill wheel evokes Nürnberg's manufacturing products. However, the main theme of the shepherd's ode is to present a friendly welcome to the foreign shepherd Clajus, who has been driven out of Saxony by the fortunes of war and, much to his amazement and relief, once again finds peace in Nürnberg. ${ }^{53}$ This story evokes a motif from Virgil's first eclogue in which not even the rustic landscape is free of outside disturbances. ${ }^{54}$ The subject also includes the ambivalent nature of a venerable historical age, which ensures stability and dignity, but in utopic depiction of the shepherd's existence is subject only to the natural cycle of the seasons; the ruins symbolize the inevitable erosions of time, thereby evoking an elegiac undertone of impermanence. Like the pastorals of the first half of the seventeenth century that combine the past greatness of the Roman Empire with images of the Roman Campagna as the utopian site of a secure and simple life in a lovely landscape, the pastorally populated Nürnberg landscape suggests timelessness, yet its noble manors, fishermen's huts, meadows, gardens and fields are also threatened by sudden destruction. However, the pictures only hint at what the text expresses with great clarity: "the raging sword/revenge for sought-after injury/and the furious turmoil of the weaponry [have] lately driven out all art and grace/ shepherds and shepherdesses are brought down among their wooly flock/all the villages/dairy farms/outlying estates and sheep farms are desolate/meadows and fields overgrown/the groves burned down by the watchfires/fruit and vegetable gardens turned into bulwarks. Instead of the leafy spruce trees, long spears and lances glistened/instead of the village organ pipes and shepherd's songs, one heard the wild battlefield cries and dying screams of the soldiers/instead of the faithful bleating of the

53 For the purposes of evoking connection to Nürnberg realities (in the text, without reference to the title image) see Althaus 2001, pp. 690-713.

54 On the literary and aesthetic tradition, see Maisak 1981; Böschenstein 2001; on the passage cited, see Althaus 2001, pp. 699-705. 
sheep/the neighing of the horses/the roll of the drums and the calls of the trumpets." 55 In the pastoral poem, the war scenario is shifted to a simultaneous temporal reality, but kept at a spatial distance, and, thus, made present in Nürnberg's pastoral landscape in the form of a latent menace. One hears and remembers what one cannot see. The war is enclosed as a prose text within the framework of a pastoral poem, enabling the poets to make a literary transformation of the vocabulary of war to portray the pastoral, "and to turn it into idyllic consolation." 56 This "bleed over" from prose to poetry, the latter of which is the mode used to represent pastoral peace, makes even more evident the fictional nature of Nürnberg's pastoral existence.

The audience for pastoral poetry is socially located in the Nürnberg upper class, those who pursue an aristocratic lifestyle or have noble status. The city and land - that is, the income from one's property - are clearly interrelated in the pastoral landscape.

In the spectacular large-format etchings by Hans Lautensack, made in 1552, shortly before the Second Margrave War, agricultural activities are broadly displayed against the backdrop of the city and on the rural roads there are mostly passersby depicted from the environs. Trade with other regions, to which the city and the patricians owe their prosperity, is only represented by two wagons. And this remains a constant feature: vedute of the areas directly in front of the city walls, which are part of the canon of views starting from the end of the seventeenth century, depict pedestrians and riders, but not the transport of goods. ${ }^{57}$ In this respect, Nürnberg dif-

55 Harsdörffer/Claj 1644, pp. 5f., quoted here from the 1648 edition: „das rasende Schwert/die Rache der gesuchten Beleidigung/und das wuetende Getuemmel der Waffen [haben] unlaengst alle Kunst und Gunst verjaget/ Schaefer und Schaeferinnen sind ům ihre lieben Wollenheerde gebracht/ alle Doerfer/Mayerhoef/Forwerge und Schaefereyen sind veroedet/Auen und Wiesen verwildert/das Gehoeltze durch die Wachfeuere veroesiget / Obst= und Blumgaerten zu Schantzen gemachet worden. Statt der belaubten Fichten schimmern lange Spiese und Lantzen / vor die Dorffschalmeyen und Hirtenlieder hoerte man das wilde Feld- und Mordgeschrey der Soldaten/ vor das fromme Bloeken der Schafe / das Wiehern der Pferde/das Brausen der Paukken und Schrekken der Trompeten.“.

56 Wording from Althaus 2001, p. 700.

57 Views from the east and from the west, each composed of three etchings of approximately $44 \mathrm{~cm}$ x $160 \mathrm{~cm}$. In return for one color copy for the First Losunger and non-color copies for the members of the Council, Lautensack received 50 gulden (Imhof 1880, p. 165; Mende 1999, pp. 337f.). Since 1531, the standard for 


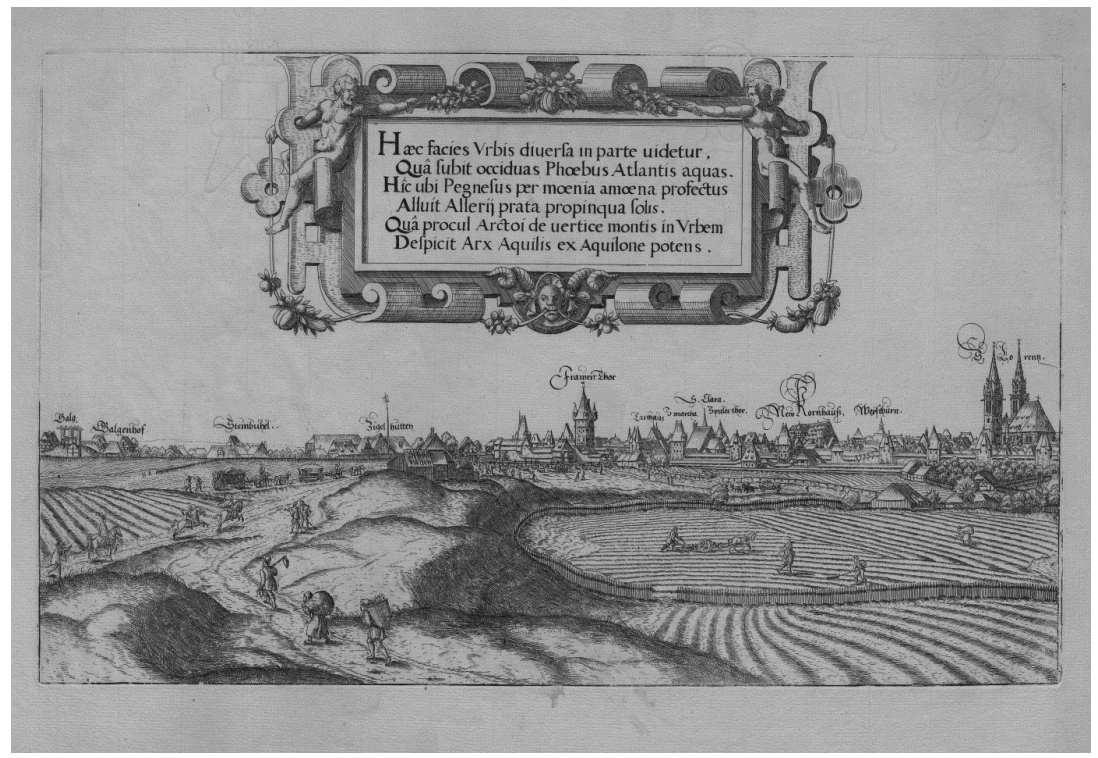

Fig. 5: Hans Lautensack: View of Nürnberg, left section (Nürnberg, Germanisches Nationalmuseum)

fered from the Dutch cities, whose vedute made the flow of goods and persons on water and on land one of their principal themes. ${ }^{58}$

There is a second way that the pastoral world of Nürnberg is a fiction and, if not utopian, at least a further reinforcement of Council policy seeking to preserve the precarious state of peace and prosperity. At the time Jan Brueghel's vedute of the environs was being printed, Nürnberg was still little affected by the Thirty Years' War. By the time Harsdörffer and Klaj took up the pastoral motif again in 1644, the city had defended itself against the forces of the Holy Roman Empire through an alliance with the

this type of vedute was set by the woodcut by Anton Woesam, which the Council of Cologne gave as a gift to Charles $\mathrm{V}$ and Ferdinand I on the occasion of their visit to Cologne. In 1594 and 1599, etchings of Ulm and Augsburg by Joanathan Sautter would follow: In Augsburg, Sautter received 100 gulden in return for the prints distributed among the Council members (Besing 1999, p. 97). Graff/Kraus, Boener, and Delsenbach depict the city gates seen from the outside.

58 As an example: Hendrick Vroom: "Views of Delft", painted in 1615 and presumably given to the Council as a gift in 1635 (Suchtelen/Wheelock 2009, No. 49, pp. 200f.). 
Swedish king, activation of a citizen's home guard, the mobilization of all households for building entrenchments, and the passage and billeting of large numbers of soldiers. In fact, it was the Council's tactics and its conclusion of an alliance with the Swedish king between 1631-32 that had allowed Nürnberg to be spared conquest by Habsburg forces. However, for the citizens, the burdens of war were considerable, and took the form of supplying the approximately 20,000 men in the Swedish forces, epidemics, inflated prices, the need for extensive borrowing and, consequently, an enormous tax burden. In addition, it was apparent that in the short term, Nürnberg was incapable of autonomously ensuring the defense of the city and its territory with its own army and militia. The tragic fate that befell Magdeburg, which had been the victim of plunder and pillage a year earlier on the command of Tilly, ${ }^{59}$ was cited in the discussions among the Nürnberg authorities during these months. With Sweden's planned departure in the fall of 1632, the Council also feared that matters could come to "an uprising and ransacking of the noble houses by the rabble," 60 and, for this reason, negotiated quartering a garrison of over 4,000 soldiers from the Swedish army.

\section{Modes of presentation}

At first sight, the 12 vedute etched in 1688 by the Augsburg engraver Johann Ulrich Kraus ${ }^{61}$ and titled "Abgezeignete schoene Landschäfftlein umb Nürnberg" [Beautiful small landscapes around Nürnberg] and based on drawings by Johann Andreas Graff, would suggest that nothing had happened in and around Nürnberg in the more than 70 years since the series by Brueghel, Isselburg, and Merian. In the sunshine under a partly cloudy sky, one again sees the country houses of the Nürnberg gentry, expressing a no-longer contemporary architectural language dating from the sixteenth century. However, the ornamental gardens are quite modern and

59 See “gantz verheeret!" 1998.

60 Cited from Donaubauer 1899, p. 74: "einem Ufflauf und Ausspolirung der fürnehmen Heuser, bevorab von dem Pöfel".

61 Abgezeignete schoene Landschäfftlein umb Nürnberg, alda bey Joh. Andr. Graff, Mahlern zu finden, Nürnberg 1688, Falk 1975, pp. 218-220. Cited by Schmidt 2000, pp. 137; the prints were first sold by von Graff, then by Jeremias Wolff from Augsburg (with numeration). See Virtuelles Kupferstichkabinett, Braunschweig, Herzog Anton Ulrich-Museum, AB 3.36ff. For a biography: Tacke 2001, pp. $420 \mathrm{f}$. 
magnificent. ${ }^{62}$ A new feature in the Nürnberg canon of pictures is the depictions of the byways around the city and their similarly unchanging city walls, which are no longer reflective of the defensive technology of the times. The images also include some places connected with fishing and leisure activities.

The ponds and swimmers in the Tulenau in the suburb of Wörth renew the motif of the Weiherhäuser (pond houses) against the backdrop of the city. ${ }^{63}$ The Pegnesian Order of Flowers is acknowledged by way of its meeting place - the peninsula on the banks of the Pegnitz just west of the city - and is already familiar from the title of the pastoral ode. If we look more closely, however, we see traces of Nürnberg's more recent history and the unchanging state of conflict with its neighbors: Ziegelstein castle

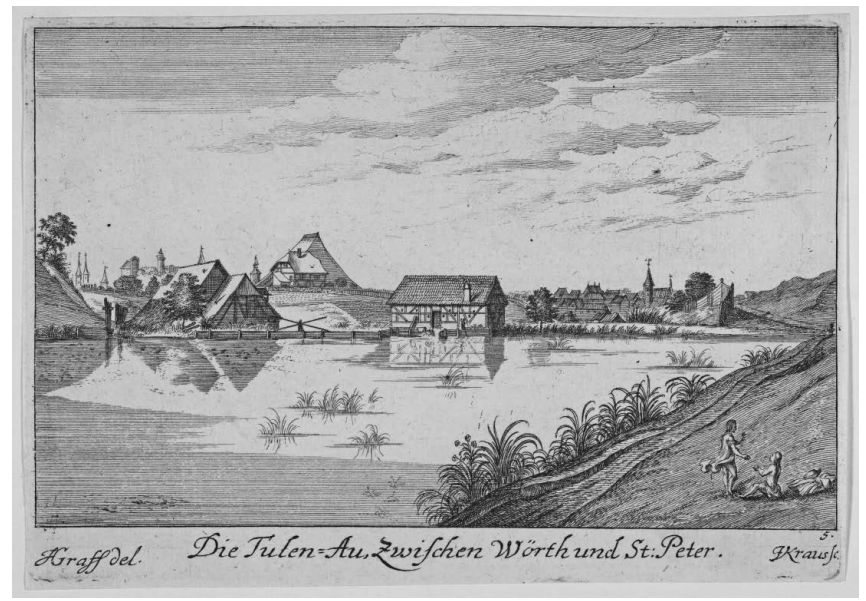

Fig. 6: Johann Andreas Graff (draughtsman)/Johann Ulrich Kraus (engraver): The Tulen-Au (Abgezeignete schoene Landschäfftlein umb Nürnberg) (Braunschweig, Herzog Anton Ulrich-Museum)

62 It is not possible to further pursue the question of how far the garden art of Nürnberg and its representation might also represent an over-compensatory reaction to the topos of the city description, by which the sole disadvantage of Nürnberg's topography was the infertility of its soil. On the topos, see Meyer 2009, pp. 250f. Especially noteworthy is: Johann Christoph Volkamer: Nürnbergische Hesperides [Hesperides of Nürnberg] Nürnberg 1708. Vol. 2 appeared in 1714. See also Martz 2008; Lauterbach 2011; Wimmer 2001.

63 On the site and history of ownership: http://www.herrensitze.com/tullnau-i.html. 


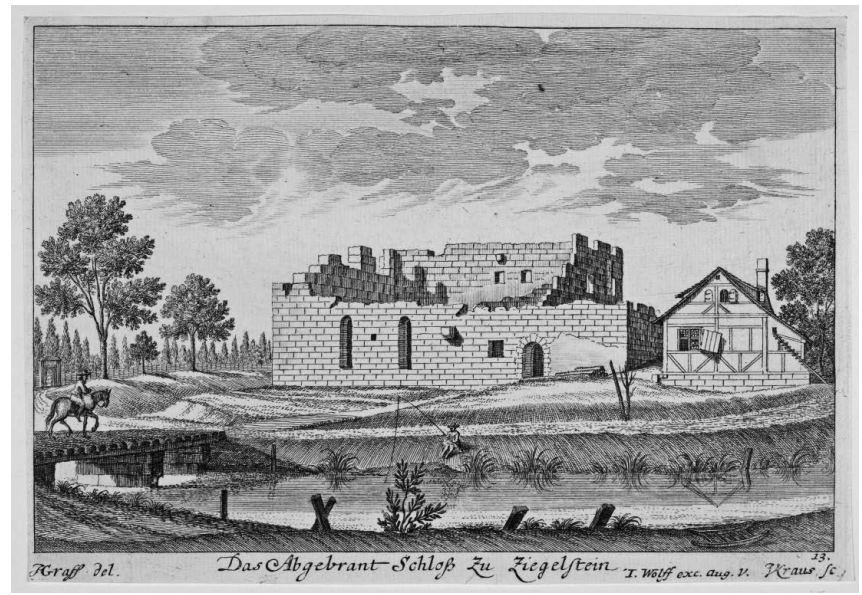

Fig. 7: Johann Andreas Graff (draughtsman)/Johann Ulrich Kraus (engraver): Ziegelstein Castle (Abgezeignete schoene Landschäfftlein umb Nürnberg) (Braunschweig, Herzog Anton Ulrich-Museum)

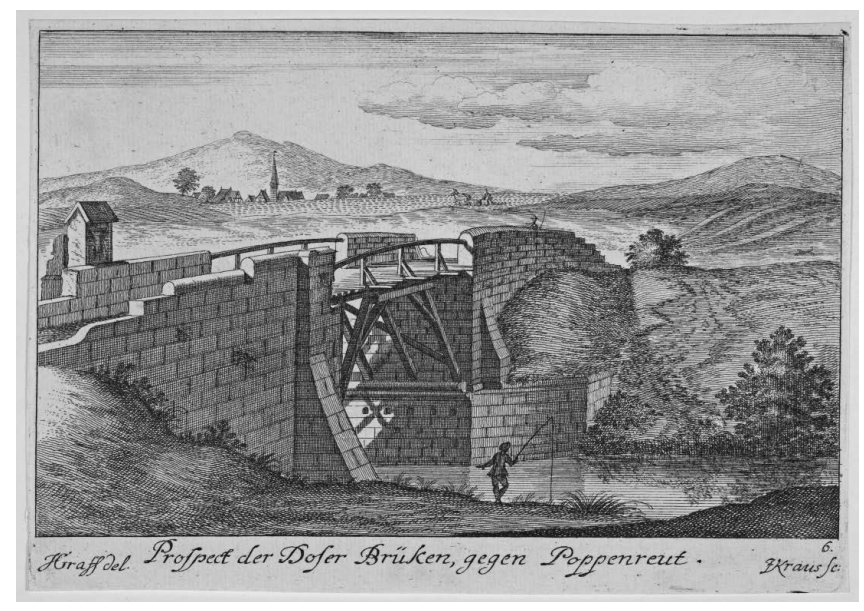

Fig. 8: Johann Andreas Graff (draughtsman)/Johann Ulrich Kraus (engraver): The Dooser Bridge over the Pegnitz (Abgezeignete schoene Landschäfftlein umb Nürnberg) (Braunschweig, Herzog Anton Ulrich-Museum)

is shown in ruins - the outbuilding with its chicken ladder is no longer in use. In fact, the Haller family seat had been restored after the Second Mar- 
grave War only to be destroyed by Habsburg troops in 1642 and not rebuilt again. ${ }^{64}$ The Pegnitz bridge at Doos reflects a second foreign element in the bucolically populated Nürnberg landscape. ${ }^{65}$ The old wayside shrine dating from pre-Reformation times and the fishing boat underneath the wood structure that replaced the stone arch of the bridge is a monument to historical time. Furthermore, for the politically astute viewer, its economic and military dimensions are evocative - the Margrave Ansbach-Bayreuth, who pursued his claims to the territory of Nürnberg with judicial and military means, regularly conducted his summer maneuvers at the Dooser bridge. ${ }^{66}$ The mood is set by the few selected figures populating the scene of Nürnberg's profound peace: fishermen, a few peasants in the field, a few persons walking along the paths, and often an artist sketching, who bears witness to the authenticity of the presentation. These are almost always background figures, and - with their emotions undefined - they draw the beholder into the scenery while leaving him to his own reveries in relation to the Nürnberg arcadia.

More rarely marked by such ambivalence are the messages that connected to the pictures of the interior of the city, but here as well one finds different manifestations. Thus, the square beside St. James Church and the local seat of the Order of Teutonic Knights are presented in identical detail in the picture series by Graff and Kraus, Johann Alexander Boener, and Johann Adam Delsenbach. In this way, information about the city's topography and buildings is offered in consistent fashion. ${ }^{67}$ However, the mode selected serves different interests and, in each instance, conveys different conclusions about the city's situation.

64 On the site and history of ownership: http:/www.herrensitze.com/ziegelsteini.html.

65 On the site and history of the mill above the bridge: http://www.herrensitze.com/ kernstein.html.

66 Willax 1979, pp. 208-210.

67 On the history of the command and the legal disputes with the city of Nürnberg, see Fleischmann 1991, pp. 118-137, with Cat. No. 33f. 


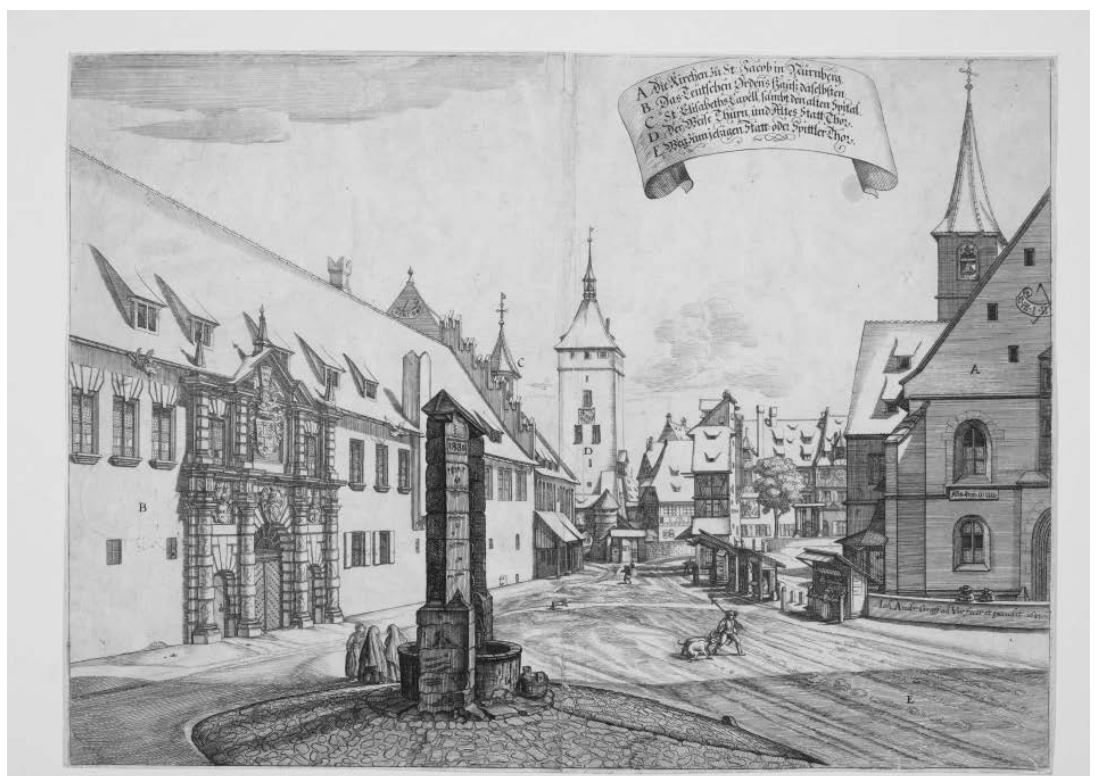

Fig. 9: Johann Andreas Graff (Draughtsman)/Johann Ulrich Kraus (Engraver): Jakobskirche [St. James Church] and Deutsches Haus [House of the Teutonic Order] (Nürnberg, Germanisches Nationalmuseum)

One's gaze is drawn each time toward the interior of the city and the White Tower; it is midday and the sun is high. Graff makes use of the incident light so that the massive rusticated portal looks like a bulwark in the smooth walls of the House of the Teutonic Order. ${ }^{68}$ Nothing is happening on the streets. A hunter is headed away from the city with his two dogs; women stand near the brook, and two idlers are leaning against the bound-

68 Urbis Noribergensis Insigniorum Templorum, Amoenissimorumque quorundam Prospectuum / [The City of Nürnberg Different Churches from Inside and Outside] Stadt Nürnberg unterschidlicher Kirchen von innen und außen, 1694 (Falk 1975, pp. 218-220.). The set, not originally conceived as a series, included four views of public buildings/facilities. The series was first sold in 1694 by Graff himself, and later by Jeremias Wolff in Augsburg. The engraver was Johann Ulrich Kraus. See Schmidt 2000, pp. 137f., on the Council's share: for the depiction of the Barfüßerkirche then under construction, Graff received 40 gulden in 1693; in 1696, 50 gulden for prints of 4 churches; 12 gulden for prints of the Zimmerplatz (Schwemmer 1981, p. 7, n. 13). The Council was thus interested in the depictions of "its" buildings, but not in the series as a whole. 
ary wall of the St. James Church, on which the draughtsman and the engraver have put their signatures. There are hardly any customers at the vending stalls, and a dog is lying comfortably in the middle of the street. A hard shadow falls on the foreground, creating an indeterminate mood, but by no means suggestive of a prosperous, populous trading city.

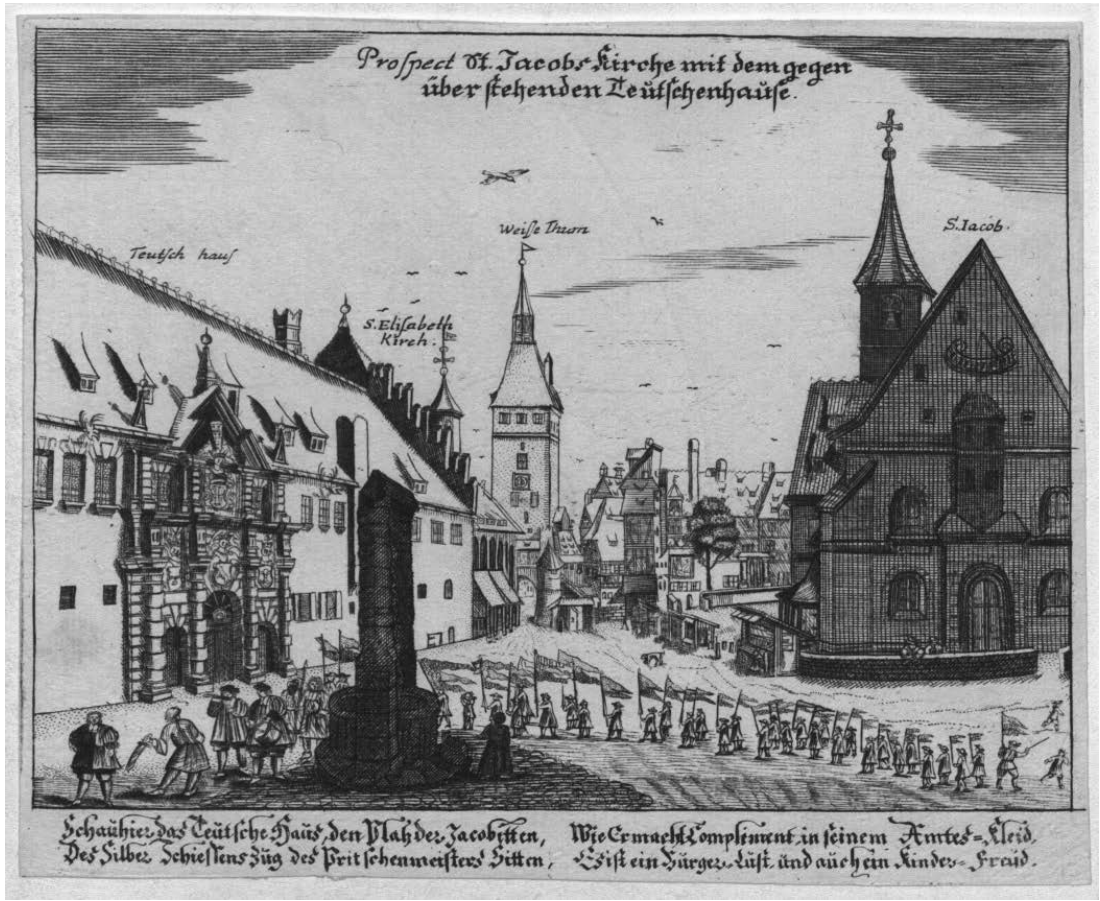

Fig. 10: Johann Alexander Boener (Engraver): Jakobskirche [St. James Church] and Deutsches Haus [House of the Teutonic Order] (Wien, Österreichische Nationalbibliothek)

Johann Alexander Boener worked with the same sources or copied the page from Graff and Kraus. ${ }^{69}$ He uses the repoussoir of the shaded black well to sharpen the contrast with the fully illuminated White Tower. $\mathrm{He}$

69 Boener's prints have not yet been widely studied. The complete collection, approximately 400 prints, is entitled: Des heil. Röm. Reichs Zierdte, bestehend in Geist- und Weltlichen Gebäuden, anmuthigen Plätzen und Prospecten inner und außer derselben: wie auch Kleider-Trachten, Handwerks-Umzügen, und unter 
also uses this as a means of composition, for a procession of "silver shooters" is running directly across the street from right to left. This is a reflection of Nürnberg's artisan tradition that was not merely tolerated by the Council but at times promoted by it as an expression of normalcy and its great importance. ${ }^{70}$ The page was included in Boener's "Trachtenbuch" [Book of Costumes] and is thus located in a double perspective. It presents the order of polity, which regulated clothing and the proper course of celebrations so as to maintain the existing social order and standardize its symbolic forms. It also transmits information about the customs characteristic of the city, and in the era of antiquarian research on mores et instituta this aroused lively interest among experts and collectors of "originals" as evidence of the city's venerable and long history. ${ }^{71}$

Finally, there is the 1726 version by Johann Adam Delsenbach. ${ }^{72}$ In this version, the scene is brightly illuminated, such that all the figures cast shadows. There is no single significant event that enlivens the streets; rather, we are confronted with a depiction of the typical everyday life of the neighborhood. The used furniture in the lively shopkeeper's market is depicted in detail. Maids are drawing water from the stream, an innkeeper is unloading freshly delivered barrels, a carriage is stopped in front of the House of the Teutonic Order, and the gateway is open. A pilgrim, symbol

ihrer Bottmäßigkeit habenden Landschafften (1702, 1708, 1722, and without date). See Müller 1791, pp. 24-40, and the selection in Schwemmer 1981; moreover Schmidt 2000, pp. 138f., 162; Boener copies prints froms his own costume book used Nürnbergische Kleider-Trachten der Manns- und Weibspersonen, 1688 (further editions 1689, 1690, 1700, Müller 1791, pp. 103f.). Boener was not sponsored by the Council.

70 On Nürnberg's Schembart Carnival, see http://www.historisches-lexikon-bayerns.de/artikel/artikel_45244 with additional references.

71 Boener 1689. We are unable to verify as yet whether the first 1688 edition of the Trachtenbuch already included vedute. We used the edition in the Bayerische Staatsbibliothek München, Bavar.14552. The same combination of costumes and vedute is also found in: Samuel Mikoviny: Kleidungsarten und Prospecten zu Nürnberg, s.l.s.d [Nürnberg, around 1730], Bayerische Staatsbibloithek, Res/ Bavar. 5177q. Instead of an exhaustive integration in the antiquarian cultural historical tradition, there is only reference here to Conrad Celtis' 1495 Norimberga, which for the first time in relation to Nürnberg, took up the theme of "mores et instituta.".

72 Johann Adam Delsenbach: 110 Views in 3 Parts: 1715, 1716, 1725: On Delsenbach's works for the architectural works of Fischer von Erlach in Vienna, see Prange 1997, pp. 101f.; Schmidt 2000, pp. 162-164, especially highlights the accessory figures. 


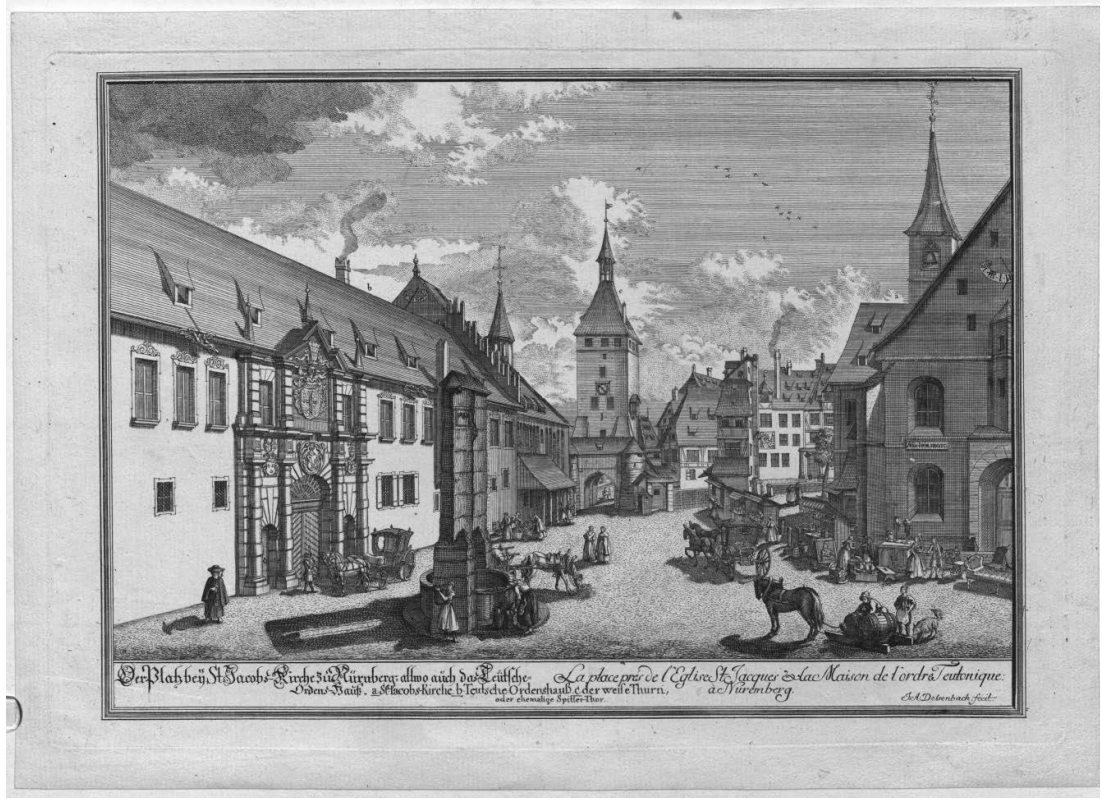

Fig. 11: Johann Adam Delsenbach (Engraver): Jakobskirche [St. James Church] and Deutsches Haus [House of the Teutonic Order] (Wien, Österreichische Nationalbibliothek)

of the Catholic enclave and the patron saint of the church, is walking away from the town. Delsenbach uses the figures and the weather to turn the city's topography into a narrative about the good function of the city-state and well-ordered collaboration of its inhabitants. There is just enough to be seen to tell a story of daily routines. For example, if you want to find out where the pilgrim is going or where the carriage came from that is arriving into the city, then you must turn the page. Whereas Graff also makes use of the medium of the pastoral in his inner city vedute to strengthen the ambivalence of the signals of defensive capability in the architecture of the city, Boener and Delsenbach concretize these suggestions through the figures that populate the scene but deepen the overall impression of prosperity.

The only way to determine the mode considered most appropriate by the Council for disseminating images of Nürnberg is to examine the funding or support it provided or withheld. We do not have a record of specific opinions being voiced in this regard by the Council of Nürnberg or by the 
councils in other European cities and territories. Both Boener's mode of presentation, which emphasized the customs of the city, and Delsenbach's mode of presentation, which depicted the city's social and economic order, were introduced to Nürnberg in a specific context that was fraught with internal and external political meanings: the construction of the city hall and its communication through prints. The medieval town hall was substantially rebuilt starting in 1616 at the Council's initiative with plans drawn up by Jacob Wolff the Younger, and its exterior was modernized. ${ }^{73}$ Two views of the emergent city hall were published in 1621. Hans Troschel etched a frontal view based on drawings by Lorenz Strauch. ${ }^{74}$ The broad façade of the city hall can be seen easily from the (fictional) viewing site the artist has selected, and the forecourt is peopled by passers-by of different classes - a theme whose narrative possibilities Delsenbach will later expand upon. The viewer overlooks the events from a high vantage point. The overview also serves as a sign of respectful distance from the seat of the city's governance and, for this purpose, indicates and sets a norm for the attitude toward the construction expected of the observer in the reality of the square. Invoking the name of God, coats of arms and inscriptions proclaim the city regiment's pledge to the eternal life of the city and city hall, by both government and the governed.

73 Mende 1979. There is a contemporary parallel in the construction and publication of the Augsburg City Hall, which took place a few years earlier. See Jachmann 2008, pp. 92ff., including additional references. For a systematic comparison of the art policies of the councils in Augsburg and Nürnberg, see Jachmann 2013, pp. 90-109.

74 Berlin, Kupferstichkabinett: Inscriptions: Norimbergensis prae se fert curia talem / Formam, quae iussu sic renovata patrum. Solis ad occasum dum cochlea serpet ab ortu / Ebibet et totum musca pusilla mare, Vrbs et Curia stet, patres populusque supersint, / Hosque regat cunctos, qui regit astra DEUS. (The Nürnberg City Hall bears such an image /of beauty to behold, as was recreated through the instruction of the senators. For as long as the snail crawls from sundown to sunrise and the tiny mouse drinks up the whole ocean, the city and its hall may stay firmly, the senators and the people may be there, and may all those be ruled by HIM, who reigns the stars, GOD). Hanc delineationem fecit \& Magnifico suo Ma-/gistratui in florentissima Norimberga test.observ./ergo dedicavit civis humilimus. Laurentius Strauch Pi: /ctor aetatis suae LXVII. Johann Troschell Norinberg/sculpsit Anno Christi 1621 (This drawing was made and dedicated to its great magistrates in magnificently blossoming Nürnberg as witnessed by the humble citizen Laurentius Strauch, Painter, in his $67^{\text {th }}$ year of life. Johannes Troschel, Nürnberg, etched it in the year of our lord 1621). See Müller 1791, p. 78. 
The second page shows the city hall in oblique view, as seen from the sloping terrain beyond the marketplace. In this print, Strauss has also depicted the wedding procession of a Kronenbraut [bride wearing a crown]. Because of its ethnographically interesting figures, this page has been copied on multiple occasions and was re-issued through to $1672 .{ }^{75}$

The views of the city hall were not commissioned by the Council, but financed instead by the generally popular mechanism of dedication: Strauch was given permission "to copy the new city hall and etch it in copper," and in exchange for the dedication of the two sheets was rewarded with 25 gulden. ${ }^{76}$ Both modes of presentation were thus acceptable.

75 Braunschweig, Herzog Anton Ulrich Museum, Virtuelles Kupferstichkabinett, http://kk.haum-bs.de/?id=h-troschel-ab3-0021, Inscriptions: Patricia de gente satam gestare Coronam/Sponsam, miraris, coronam Norica in Urbe? sinas. Expediam paucis: quoniam illa Corona puellas / Inter, ei merito nonne Corona datur? (Are you wondering how a bride from a Patrician family came to be wearing a crown in the city of Nürnberg? You should indulge her. I will explain it all to you in a few words: because this one is the crown among the young women, shouldn't she accordingly be given a crown?). Feci, quod, potui, potui, Christe, dedisti, / Perfida fac melius, Si potes Invidia. Laurentius Strauch pictor et Ex: HTroschell fe: Norinb. (I have done what I wished, I wished [what] you, Christ have given me. Make it better, perfidious envy, if you want.) For support in the reading and for the translation of the inscriptions into German, I am very grateful to Angelika Fricke. The date 1621 is found here on a tablet on the wall of a house on the left. See Müller 1791, pp. 78f., with evidence of the altered later prints through 1672. For the crowned bride as an attraction see Misson 1701, p. 86 with a copperplate. Misson's sojourn in Nürnberg dated from 1687.

76 Mahn 1927, p. 27 with n. 2: ,das neue rathhaus zu conterfaiten und ins kupfer zu stechen". In Augsburg, for the representation of the book by Wolfgang Kilian, the text has been preserved, in which the engraver asks the Council for authorization of dedication in 1614 and is thereupon paid 25 guldens as compensation for delivering 25 reprints of the three engravings. The same procedure can be presumed for Lukas Kilian's engraving of the City Hall (Schmidt 2000, p. 67). 


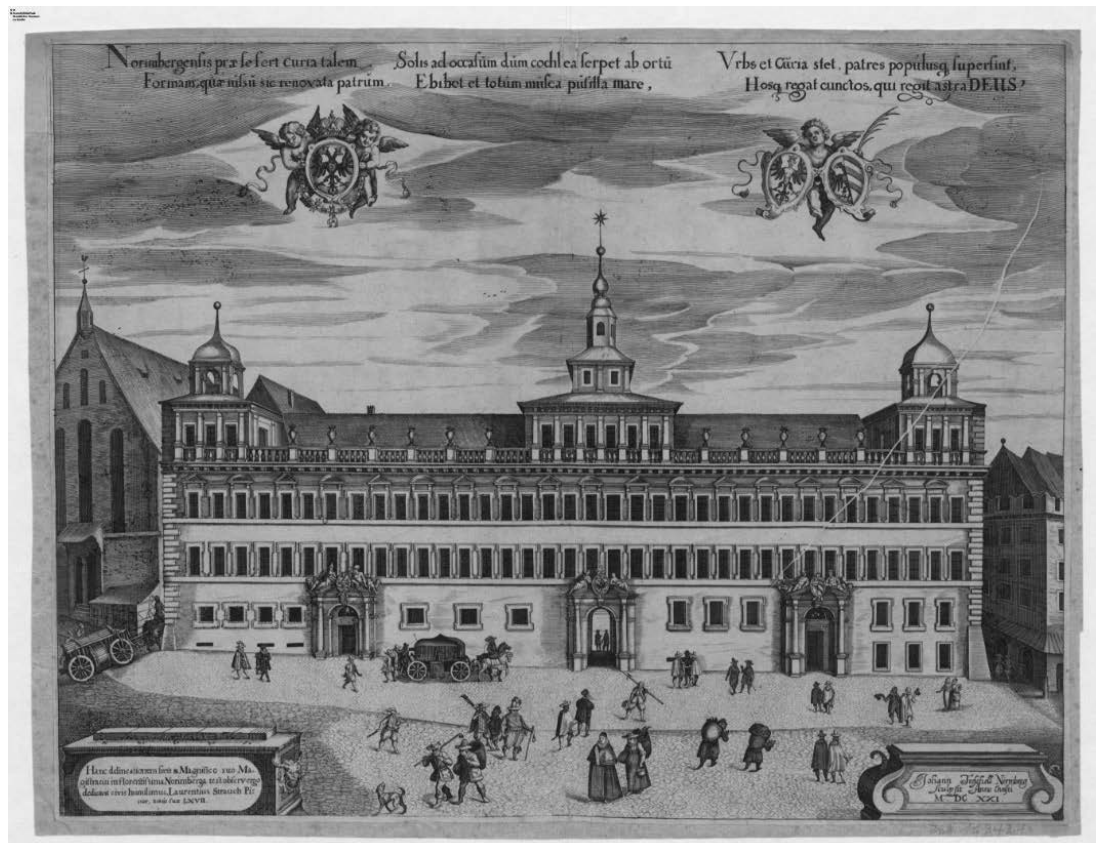

Fig. 12: Lorenz Strauch (Draughtsman)/Johann Troeschel (Engraver): The City Hall (Berlin, Stiftung Preußischer Kulturbesitz, Staatliche Museen zu Berlin, Kunstbibliothek)

From other examples of the Council's dealings with bids from draughtsmen, letter painters, and engravers, it becomes apparent which images kept with the Council's wishes and received its financial support: ${ }^{77}$ The Council primarily supported presentations that had the military fitness of the Nürnberg citizenry as a theme. This included the festive display of weapons and manpower as well as shooting contents with Falconen [cannons], published for the first time by Peter Isselburg in 1614 as an example of the Council's foresight and preparedness. ${ }^{78}$

77 On the use of visual media by the Augsburg Council in general, see Jachmann 2008 , pp. 70f. There is no overview about the system of dedication in the imperial cities. There are a few hints in Besing 1999, pp. $96 \mathrm{f}$.

78 Fischer/Maué 2014, No. 75, pp. 84f., on the stamping of medals; Hampe 1904, p. 473 , Nr. 2675. Isselburg's prints became the model for the publication of a maneuver [Stückschießen] by Georg Christoph Eimmart, 1679 (Fischer/Maué (2014), 


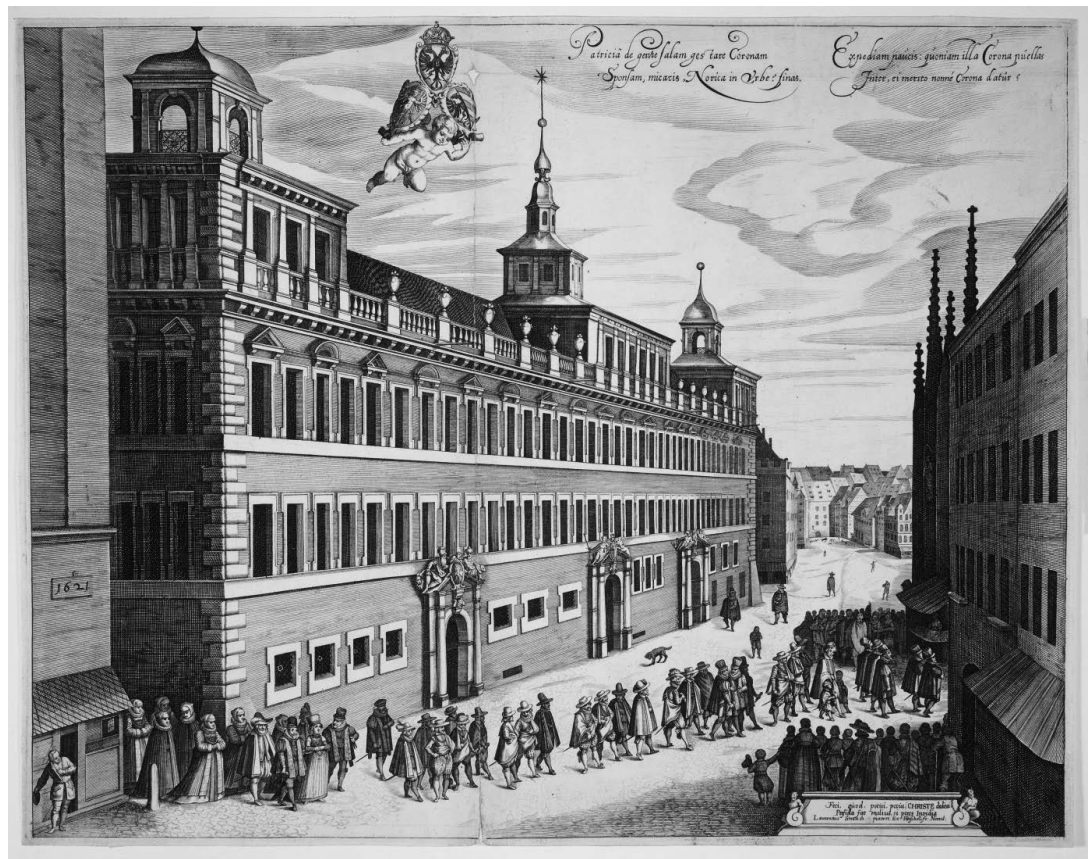

Fig. 13: Lorenz Strauch (Draughtsman)/Johann Troeschel (Engraver): The City Hall (Braunschweig, Herzog Anton Ulrich-Museum)

The emphasis in all of the illustrations of these shooting contests is on good military order, as evidenced by added side scenes of smaller, manageable or well-managed interruptions, such as child onlookers, passing horses, and similar motifs. Nürnberg's military strength, with its own armory and troops that could be deployed against foreign enemies, is also a major theme for Kraus, Boener, and Delsenbach. They painstakingly sketched out the sentry boxes on the towers and chain barriers intended to aid soldiers and law enforcers in case of internal or external threat. Delsenbach's vedute were welcomed by the Council, and it granted him 30 gulden for each of the first parts in 1714 and 1715, and 24 gulden for the

Nr. 134, pp. 124f., the Council's remuneration in this case was 36 gulden; see also the description and presentation of the maneuver, 1671 (Dresden, Sächsische Landesbibliothek)). The Stückschießen of 1733 was published in both medals and engravings (Fischer/Maué 2014, Nr. 246-249, pp. 206f., Engravings by an unknown engraver published by Johann Georg Purschner). 


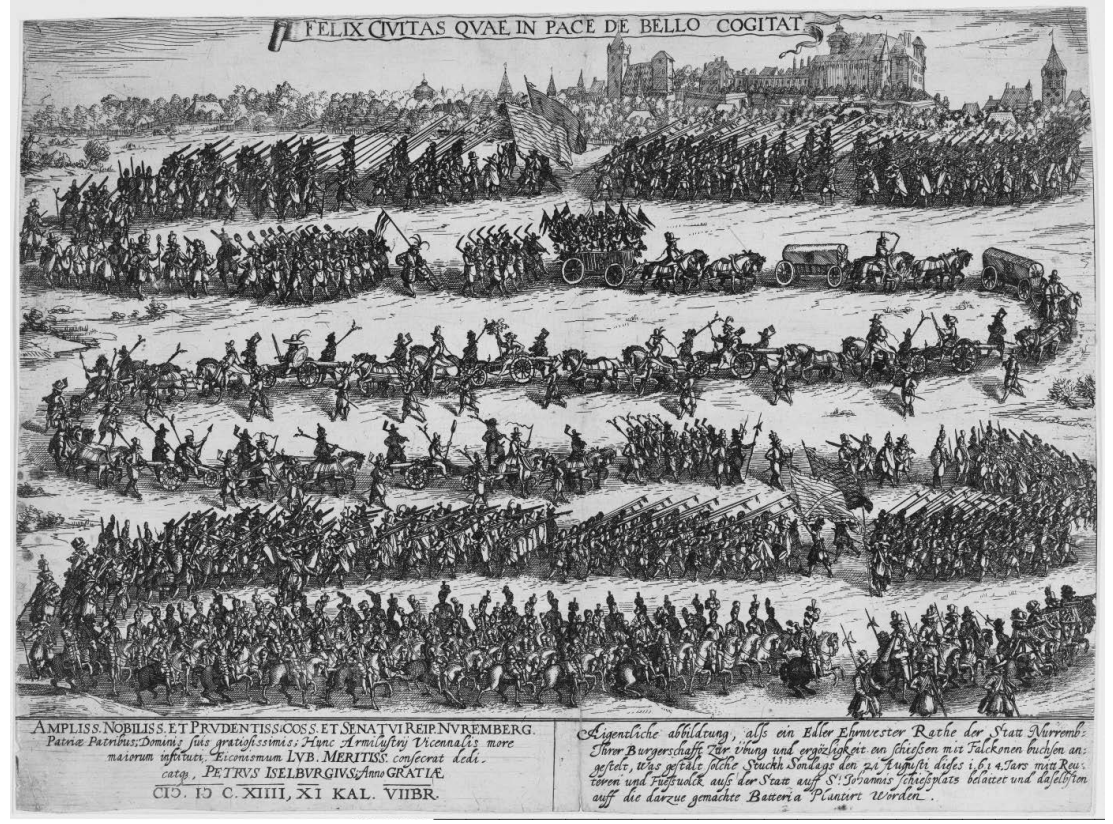

Fig. 14: Peter Isselburg (Publisher): Das Wettschießen mit Falconen, [Shooting Contests with Cannons] 1614 (Nürnberg, Germanisches Nationalmuseum)

1725 series. ${ }^{79}$ The most venerable medium, the minting of medals, was commissioned by the Council itself. "The vigilance of the fathers of country / grants security to council and citizens" was the inscription on the largest of the three medals for the 1733 military review and shoot. ${ }^{80}$ In general, the Council paid more attention to texts and medals than to pictures and took special interest in their messages. One would expect nothing else in the prolonged process of transition from orality to literacy, for this attitude toward texts is grounded in an understanding colored by Protestantism (Lutheranism) that accepted the need to use images as a medium of information and education, but sought to keep them under tight

79 Bach-Damaskinos 2006, p. 17.

80 Medal minted by: Peter Paul Werner (Fischer/Maué 2014, No. 246-249, pp. 206f.): „Der Landes Vaetter Wachsamkeit / Schafft Rath und Bürgern Sicherheit.“. 
control, especially in relation to inner imaginings and "internal images." 81 The difficulty of this undertaking may have led to a general desire for unambiguousness in images; pictures in which the information about topography was amplified or even obscured by artistic, emotion-inducing means seemed less opportune and thus failed to pique the Council's interest. The ambiguity of these images extends further: by maintaining a focus on the controlled and controllable conditions of the townscape including its security measures, the presentations highlight the possibilities for action on the part of the city regiment and on the good order for which it is responsible. The images that overlay this information with an ill-defined atmospheric element, because their aesthetic mode is part of the pastoral tradition, might also be understood as evidence for the underlying precariousness of human existence, which cannot be resolved by a mere human regiment, but only in keeping with God's divine plan in the final judgment. Thus, we might infer that the Council refrained from adopting the pastoral images of Nürnberg to communicate political realities not only because of their ambiguity, but also because of their implicit reference to the ultimate futility of all human regiments.

The reception of these pictures, like the literary productions, thus shifted to the private (familial) or the semi-private sector. Here, again, we should draw a distinction: for both printed images and printed texts, their reception may be co-determined by their inherent characteristics, but once an image or text was "on the market," neither its audience nor its opportunities for seeing them or reading them are regulated. Prints - especially small-format prints - were created exclusively for individual consumption, and in the early modern period this principally meant a community of the like-minded and connoisseurs. By contrast, the literary productions of the Pegnesian Order of Flowers also had a semi-public nature at those times when they were recited at weddings, festivals, and political events, and before they were disseminated in print similar to works of architecture art, and thus reached an audience not predetermined by place, time, or social status.

In broad continuity, there was a predominantly concretizing narrative mode in the city views ever since the first decades of the sixteenth century that sets aside specific realities with a great diversity of picture motifs, all serving to underscore the defensive strength of the city at peace. Once we

81 Here only: Berns 1993, pp. 35-72. 
try to assign precise figures and measure the presentations in detail, this becomes a mystery. In this respect, the attitude in Nürnberg is distinguished from that in other imperial cities by its greater anxiety about dealing with exact information. For a long time, no map of the city was published, and Sebastian Münster had to print his "Cosmographia" minus an image of Nürnberg. ${ }^{82}$ The Council commissioned Jörg Pencz to create the first model of the city, ${ }^{83}$ but similar to other models and maps, it seems that it was displayed in the war room, a place that was inaccessible to unauthorized persons. Later independent initiatives on the part of Hans Baier (1540, model) ${ }^{84}$ and Hieronymus Braun (1608, map) ${ }^{85}$ did end with the Council paying a remuneration but with the strict stipulation that no further copies be prepared. As diligently as the Council pursued maintaining secrecy about its own city, it made great efforts to develop information on other cities and on potential enemies within the city: the Commandry of the Order of Teutonic Knights, subordinate directly to the Emperor, commissioned the cartographer Hans Bien in 1624 to create precise architectural surveys of the buildings. The Council made illegal copies of this document but did not distribute them, since after Sweden's withdrawal from Nürnberg the buildings of the Commandry had to be returned to the Teutonic Order. ${ }^{86}$ This mode of true-to-scale surveys with perspectival or orthogonal views of the buildings, which thus combined accuracy with graphic clarity, was subjected to scholarly reflection after it was introduced in the town book by Braun and Hogenberg and deemed especially versatile. Not only could one read information of every kind from the images and avoid dangerous trips, but, much more to the point, architects could also discern the unique features of the city's fortifications in this

82 Münster 1550, p. 650: "Picturam urbis libenter exhibuissem, sed obtinere nequivi." The sentence is absent in the German edition, as is an image.

83 Schäfer 1898, p. 30.

84 Schäfer 1898, p. 38: Behaim received 40 gulden, "with the provision that he would not make any more of the same, unless the Mayor had given permission for such.".

85 Id., p. 83: The Council commissioned Braun to hand over all miniaturizations of the plan: "we should also find out from him whether he has any model or reduction of this work, and require of him for these as well; as for all other similar ones to do the same.".

86 Fleischmann 1991, p. 119, with reproduction of the drawings. For examples from other cities, see Timann 1993, pp. 143-147. Generally concerning this practice, see also Schnellbögl 1966, pp. $21 \mathrm{f}$. 
way. ${ }^{87}$ It is understandable against the backdrop of such discussions that while the Council did enable, tolerate, and even promote viewing of the vedute as a whole, since they served to promote the well-being of the city state, they did not tolerate views and plans that were orthogonally depicted and thus provided exact information that could be used, for example, to install artillery emplacements. The first surveyed city plan that was printed to be accessible to a wide audience was created without being subject to the control of the Nürnberg authorities. This was a depiction of Swedish fortifications that accompanied the related report in Matthäus Merian's "Theatrum Europaeum." 88 From this moment on, it became pointless to try to censor the publication of views of Nürnberg made from a surveyed map of the city.

\section{Concordia}

Over the centuries, the Council appears to have been less fearful of outside danger than of civil disorder. ${ }^{89}$ Celtis was the first to document the history of the instruments of power used by the Nürnberg Council to rule the populous city: "With good words and harsh corporal punishment" it was possible to rule the city without rebellion or insurrection. The understanding citizens were responsive to argument, but the rabble could only be ruled by means of the threat and enforcement of such penalties. ${ }^{90}$ In making this distinction, Celtis is fully consistent with the direction that the Council

87 Here according to the German edition: Braun/Hogenberg 1582, Preface, not paginated. Regarding incorporation in contemporary discussions on cosmography and chorography, see Nuti 1994, pp. 105-128.

88 Abelinus/Merian/Oraeus 1646, on p. 655. See Wüthrich 1993, p. 166, II/Table 52.

89 For examples from the fifteenth and sixteenth centuries, see Meyer 2009, p. 391.

90 Celtis 1921, Cap. 13, pp. 185f.: "Caesar Fridericus dum Romae consecrationem coronae a pontificem, ut imperatores nostri ex religione solent, accepisset utque Norimbergam rediit, populi multitudinem effusam ante portas undique videns et, ut urbem intrasset, civitatem in populum effusam, obsessas undique plateas et tecta laborantia et velut diluvia quaedam vidisset, seniorem urbis, qui tunc laevae eius adequitabat, interrogavit, quonam ingenio et arte tantam multitudinem sine seditione et tumultu regerent et continerent. At ille, ut vir veneranda canitie et summa animi prudentia erat, „Verbis“, inquit, ,imperator invictissime, et gravibus pecuniariis corporisque poenis id efficimus", significans ingenuos cives verbis et piis adhortationibus monendos esse hisque se emendare, plebem autem ut servile et indomitum vulgus nonnisi corporis poena aut pecuniae mulcta a delictis arceri de- 
would follow over the ensuing decades, but despite the extensive editing of his text in the German translation commissioned by the Council, the passage was still in place at the start of the sixteenth century. ${ }^{91}$ The fear of uprisings was so fundamental to the Council's policies that through a decree of damnatio memoriae, the 1349 Guild Rebellion was erased from the city's memory, and all public assemblies were forbidden. ${ }^{92}$ They even went so far as to delete the by then well-known history of the Council's exercise of force, including the taboo word "uprising," from Merian's later widely disseminated "Topographia Franconiae."93 Citing the explicit threat that it could do harm to this portion of the book, the Council told the publisher: "For the question of how such a large populace could be governed, leave out the word "uprising" and instead tell how the Council ruled such a powerful citizenry, and further, do not mention the breadth or depth of the trenches, nor the number of citizens, but instead, leave these things vague and in generalities." rare proof for the mechanisms to which the engravers were subjected; one could only anticipate sales of the goods in Nürnberg, let alone a gratuity from the Council if the product withstood censorship.

The Council had reason to be concerned. The number of anonymous expressions of protest in written and more rarely pictorial form - known as pasquills - seems to have increased, especially during times of crisis. Typical themes of extreme criticism and grounds for death threats included the excessive costs of city expenditures (city hall construction) and to entertain patricians (pompous wedding celebrations) - themes that were positively presented in the engravings of 1621 - in disproportion to pover-

bere ad cohibendaque peccata plus timorem quam pudorem apud vulgum valere. Vox digna et salutaris rei publicae cunctisque civitatum rectoribus et principibus memoriae tradenda!" German edition: Fink 2000. See also Meyer 2009, pp. 298 313 and p. 397; Israel 2012; the assessment that it was hard to rule a populous city can be traced back to Aristotle's Politics (Book VII, p. 4f.), as already reported by Johannes Cochlaeus 1960, p. 84.

91 Arnold 2004, pp. 100-116; Meyer 2009, pp. 297-304.

92 Meyer 2009, pp. 391ff., with extensive confirmation from the fifteenth and sixteenth centuries.

93 Merian 1648, p. 64.

94 Sporhan-Krempel/Wohnhaas 1967, pp. 82-88: „Bey der Frag, wie ein solche gross Meng regiert würde, das Wort ,Aufruhr' auszulassen und dagegen zu setzen, wie der Rat ein so starke Burgerschaft regiere, ferners die Weite und Tiefe der Gräben nicht, auch die Zahl der Burger ebenfalls nicht zu benennen, sondern es indefinitive und generaliter zu setzen.“. 
ty, hunger, disease, and draconic punishment for violations of the dress code; the continuation of the economic crisis from the burden of extreme levies as the object of criticism by the merchants and, unpaid wages as the grievance of the military. "By night we are going to shoot you through your windows and by day we will throw stones at you, you are responsible for turning many good people into thieves and robbers, we've been patient for long enough [...] before God and the world, we will get our money that we've honestly earned." 95

Beyond recognizing a general danger of unrest, the Council also saw a threat to its very form of rule. Expert assessment of another pamphlet concluded that the author was a "plebeian who had picked up some hint of regimental matters, but wasn't able to put it all together." For this man, the contemporary form of the aristocratic regiment was "an abomination, and he wanted to introduce democracy, and if he and his ilk were just able to get their money back from the Losungstuben [revenue office], they would be ready to drive religion and polity one and the other to rack and ruin." 96 The Council always instituted special measures when the criticism was not merely local and expressed by the "common man," but instead when it saw its reputation threatened regionally and in media disseminated among persons of high rank. The affair triggered by a medal circulated in a printed text at the 1731 Leipzig Fair occupied the Council's attention for several years, until it was able to convict the creator. The persiflage regarding the Nürnberg medallions at the end of the sixteenth century was so successful and the mockery so caustic regarding a highly esteemed medium that the Council felt directly threatened; greed, injustice, arrogance, contempt, hypocrisy, and falsehood replaced the usual catalogue of sovereign virtues that the Council never tired of claiming on its own behalf. ${ }^{97}$

95 Pamphlet 1635, as cited by Sporhan/Wohnhaas 1967, p. 87: „Bey der nacht wellen wir Euch durch die Venster schiesen und bey Dag wellen wir Euch mit steinen zu dot werffen, ir macht dass mancher Erlicher man zu einem Dieb und Rauber muß werden, mir haben uns lang genucht gedultet [...] unser gelt welen wir haben vor Gott und der welt haben mirs redlich verdient.".

96 Müller 1959, pp. 127f.: ,plebejus, welcher von Regimentssachen hat etwas läuten, aber nichts zusammenschlagen hören [...] ein Greuel und wollte gern Democratiam introduzieren, und wenn er und seinesgleichen nur seine Gelter von der Losungsstuben hetten, möchte Religion und Polizey eines mit dem anderen zu Grund und Boden gehen.".

97 Hampe 1918, pp. 246f.; Müller 1959, pp. 130f. There was special anxiety, because at first the Council assumed that the medal had actually been minted. In fact, there 
In her study on Nürnberg's literary legacy, Carla Meyer concluded that unlike in other imperial cities, the Council did not actively use chronicles or other literary forms to create a self-image of the city. Instead, like the princely states, it drew upon the tools of aristocratic secret politics. Keeping secrets and articulating them to those who were not in the know - the "common man" were not by themselves sufficient to maintain the stability of the Council's rule. The group of council-eligible families, which had proven their worth by tradition, status, and by their unity, were obligated instead to prove the legality and proper exercise of their rule by means of their contributions to the common good. Therefore, mistakes, just like the transgressions of individual council-eligible families or their family members, risked shaking the very foundations of rule. Along these lines, Valentin Groebner has shown that power relationships in Nürnberg in the fifteenth and sixteenth centuries were not quite as harmoniously balanced as tradition would have us believe. The Council was not fully homogeneous as had been so consistently claimed ever since the sixteenth century; to maintain order, it was always having to find a balance between old established members and office-holders and new arrivals and wealthy parvenus. ${ }^{98}$

Over the centuries that followed, this distribution of power had to be confirmed, especially during crises, and affirmed under oath. In 1632, when the Council wanted to join the alliance of the Protestant Estates with the Swedish King Gustav Adolf, and thus to terminate the age-old principle that the imperial city was forever loyal to the Emperor, it felt obliged to affirm this decision by polling the Genannten [Chosen] of the Great Council - a group of approximately 500 persons - and to subject skeptical members loyal to the emperor to criminal prosecution. ${ }^{99}$ On the surface, the Council was able to persuasively demonstrate over a long time period that the city was "nobly" ruled and that good order prevailed. Thus, Christoph Scheurl's 1516 "Epistola" was widely distributed in both Latin and German, with its claim that newcomers and the "common folk" could not participate in the government, "which is entrusted solely to all powers of God and the good rule of those few whom the Creator has endowed

were only printed fictional descriptions; the author, Johann Philipp Andreae, had been instigated by the merchants. Fischer/Maué 2014, Nos. 333, 267, with illustrations of the print.

98 Groebner 1994, pp. 279-308.

99 Willax 1991, pp. 123-173. 
with all things and nature with superior wisdom."100 From the Council's viewpoint, Nürnberg's 'res publica' had the form of an aristocratic oligarchy, according to the Aristotelian classification, comparable to the Frankish landed nobility, fiefable as well as having been endowed by God with the necessary competencies - with wisdom - to exercise the powers of government. ${ }^{101}$

However, excessive ambition on the part of some members of the group of council-eligible families also threatened the maintenance of rule, so long as these groups signaled external stability through homogeneity and harmony. For this reason, any involvement with representation through external signs - with all that could be regarded as an appropriate signal in the respective frame of reference - took on a degree of significance only hinted at by Meyer and Groebner. As was customary in the South German imperial cities, the Council made use of complex allegorical images for this purpose, which were at first directed to an educated audience. The Council itself was part of this audience; self-affirmation was not a insignificant objective of this allegorical pictorial program. When it seemed opportune, ruling wisdom was made public: this was especially the case for the publication of the statutes of 1564, which were modeled on the governance reforms decreed by Emperor Karl V in other imperial cities. They were directed - according to the preface - at being accessible to the "common man," and to disseminate knowledge about the exemplary, timehonored city regiment, but only after the Council had initially complied with the request by neighboring cities to maintain secrecy. ${ }^{102}$ The statutes were equipped with an allegorical frontispiece, which in no uncertain terms summarized the Council's view about the foundation of the state.

100 Scheurl 1874, p. 791; Meyer 2009, pp. 323f.: „diweil alle gwalt von gott, und das wolregirn gar wenigen und allein denen vom schöpfer aller ding und der natur mit sunderlicher weyshait begabet sein, verliehen ist." The Latin version: "Advenae et Plebei nihil possunt, neque plebeiorum est regere, quum omne regimen a Deo sit, et bene regere paucis admodum concessum, his scilicet qui genio singulari a Summo rerum pontifice et natura quoque dotati conspiciuntur." (Scheurl 1999, p. 29).

101 For a comprehensive presentation, see Gundling 1706, ch. 2, p. 30; further evidence, among others, from the Emissary Reports in Meyer 2009, pp. $472 \mathrm{f}$.

102 Huntebrinker 2009. 


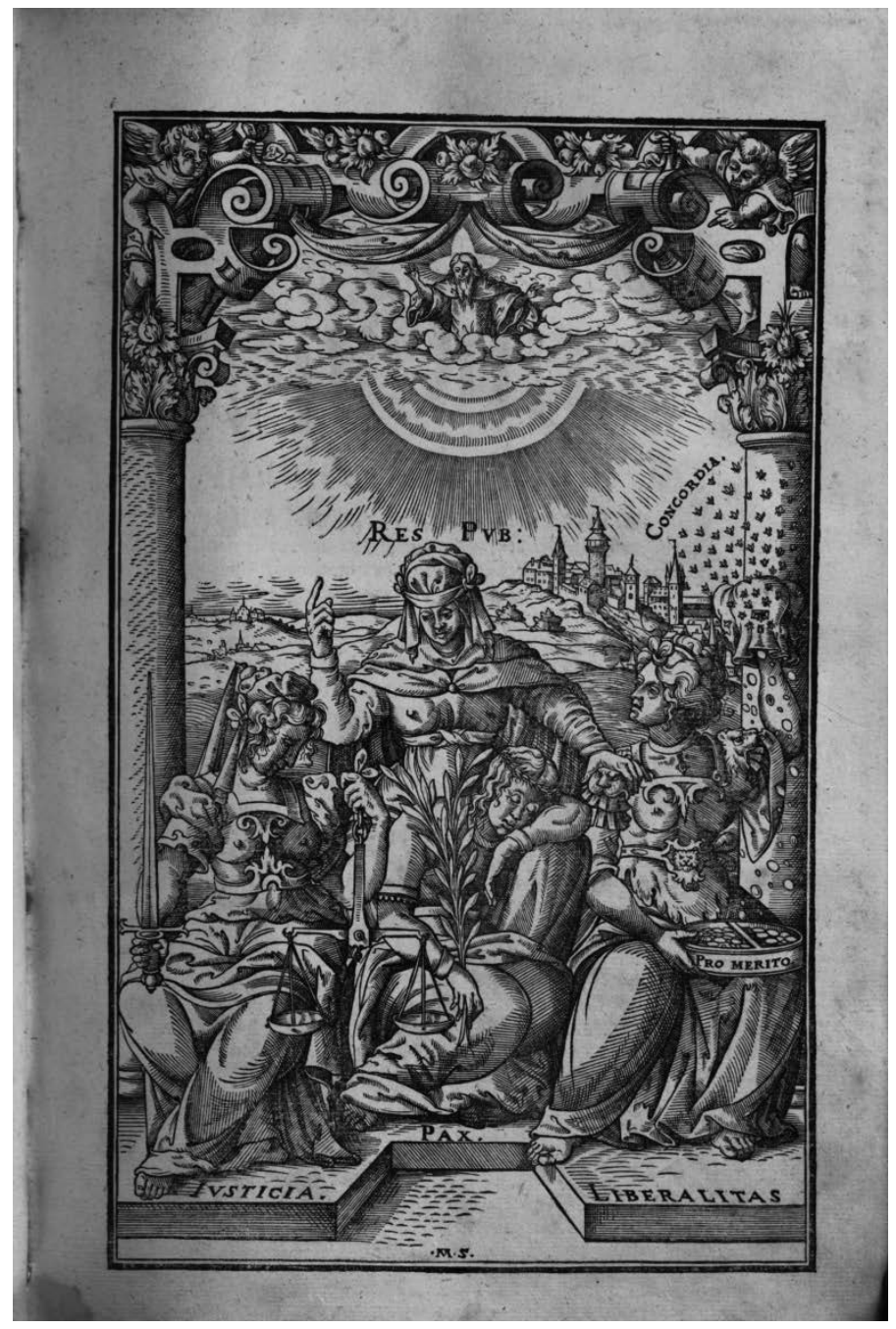

Fig. 15: Master M.F.: Allegory of the Imperial City of Nürnberg, Der Stat Nürmberg verneute Reformation [Renewed Reformation of the City of Nürnberg] 1564, Frontispiece (München, Bayerische Staatsbibliothek)

Under the protection of God the Father, the Republic (res publica) is seated on her throne, calling the attention of her protégées to this source for the splendor of city and territory. Peace (pax) sleeps in her lap, visually enhancing the statement of deep, undisturbed tranquility - yet justice (jus- 
titia) and munificence (liberalitas), the foundations of the state, are providentially protected by breastplates. Munificence distributes by merit (pro merito) the revenues generated by the harmonious bees (concordia), which swarm from the city - symbolizing an industrious and united citizenry. ${ }^{103}$

Harmony is a central theme in Nürnberg's political allegories and consistently marks the self-presentation of the Nürnberg patricians as a group. It also forms a foundation for the emergence and preservation of an "urban core identity," 104 which is produced and continuously reaffirmed in fictional texts and image series instead of the texts kept under lock and key in the town library. Unlike the landed gentry and unlike the ruling dynastic families, the Nürnberg patricians hardly ever used the fine arts and architecture to leverage or elevate their standing through representations of their competitive status within their own group. There was virtually no rivalry among the council-eligible families - and given the basically paragonal system of artistic representation in the early modern era, this is a remarkable phenomenon. ${ }^{105}$ After the Thirty Years' War, there was virtually no private construction activity in the city, and in rebuilding the country estates, they maintained the ancient appearance of their buildings. The dress code precluded pretensions among low-ranking citizens, and it also served to keep the council-eligible families in line. The city and its environs were represented in image series that underscored homogeneity. Nobody stepped out of line. A look was promoted, even if it was seldom proactively demanded, which generated an identity of the city and its environs of rare unity and thus recognizability. Nürnberg was characterised by

103 Der Stat Nürnberg verneute Reformation, Nürnberg [Valentin Geisler], 1564. We have used: facsimile, digitalized, Heidelberg, University Library. http:// digi.ub.uni-heidelberg.de/diglit/drwNuernbergRef1564/0006. The print was reprised on a broadsheet for the 1635 Peace of Prague: Des H. Römischen Reichs von Gott eingesegnete Friedens-Copulation [The Holy Roman Empire consecrated by God's Covenant of Peace], among others, Nürnberg, Germanisches Nationalmuseum, Veste Coburg Art Collections: See Schilling 1990, pp. 185ff. (for the Nürnberg provenance); Harms 1983, p. 209; Burckhardt 1998, pp. 95f.

104 A term in Meyer 2009, p. 391.

105 The pre-Reformation patrician class behaved quite differently; in the religious memorial foundations, one can consistently observe a competition (cf. Schleif 1990). A famous exception for building activities in the post-Reformation period is the house that the - non-Council eligible - merchant Martin Peller had built by Jacob Wolff starting in 1602 on the Egidienplatz. The façade was characterized by the structural support of a juxtaposition of columns and pilasters (Schaffer 1934). 
long rows of narrow houses under steep roofs with roof dormers, windows with crown glass panes at a time when elsewhere, plots were becoming larger, and longitudinally terraced buildings windows with large panes were providing more comfort.

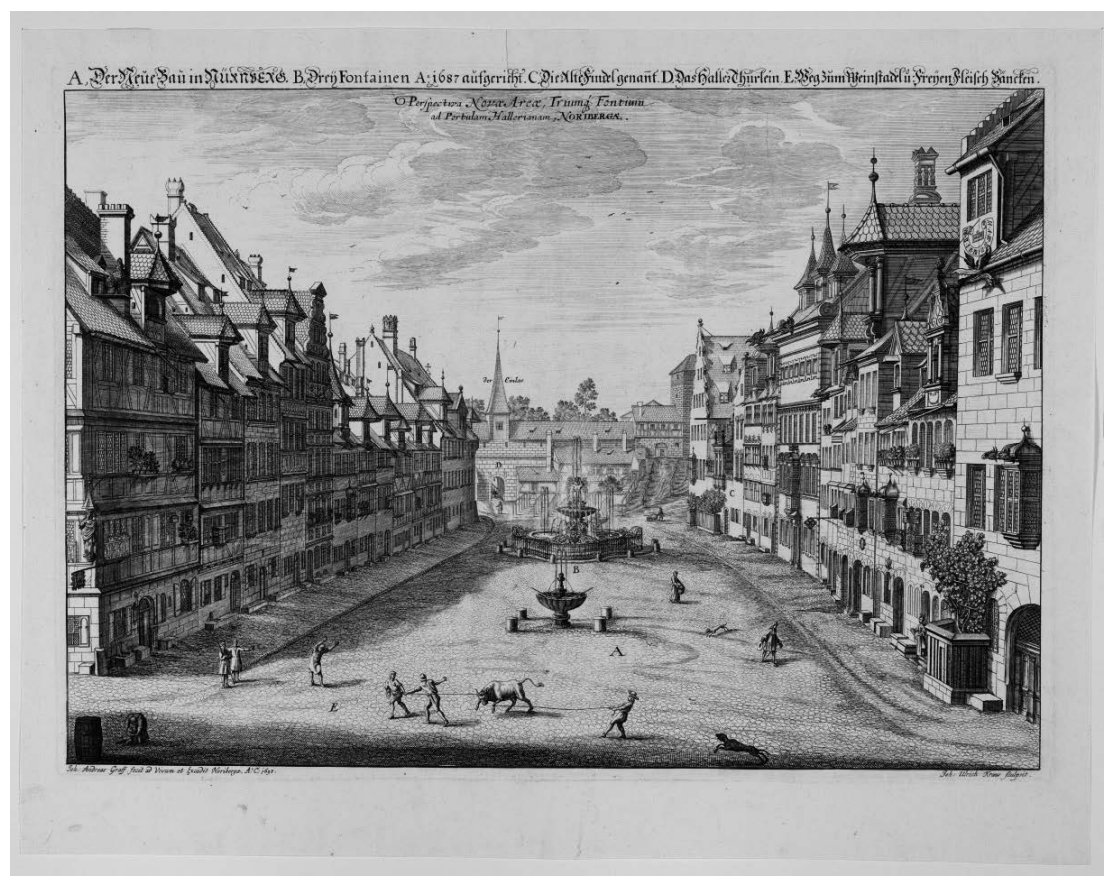

Fig. 16: Johann Andreas Graff (Draughtsman)/Johann Ulrich Kraus (Engraver): Der Neue Bau [The New Building] (Braunschweig, Herzog Anton Ulrich-Museum)

There were also long rows of identical graves in the cemeteries, and only in extremely exceptional cases did this allow any individual personalities to stand out. ${ }^{106}$ This meant insistence on regionally typical clothing, from which social status could be easily read. This uniformity is expressed especially well in one form of publication - the series - and one pictorial mode, which tends toward concreteness in its wealth of detail and avoids ambivalence: the pictures do show small, everyday mishaps and misad-

106 Pilz 1984, pp. 65-69; Trechsel 1735.

26354-175, am 26.04.2023,15:10:48 


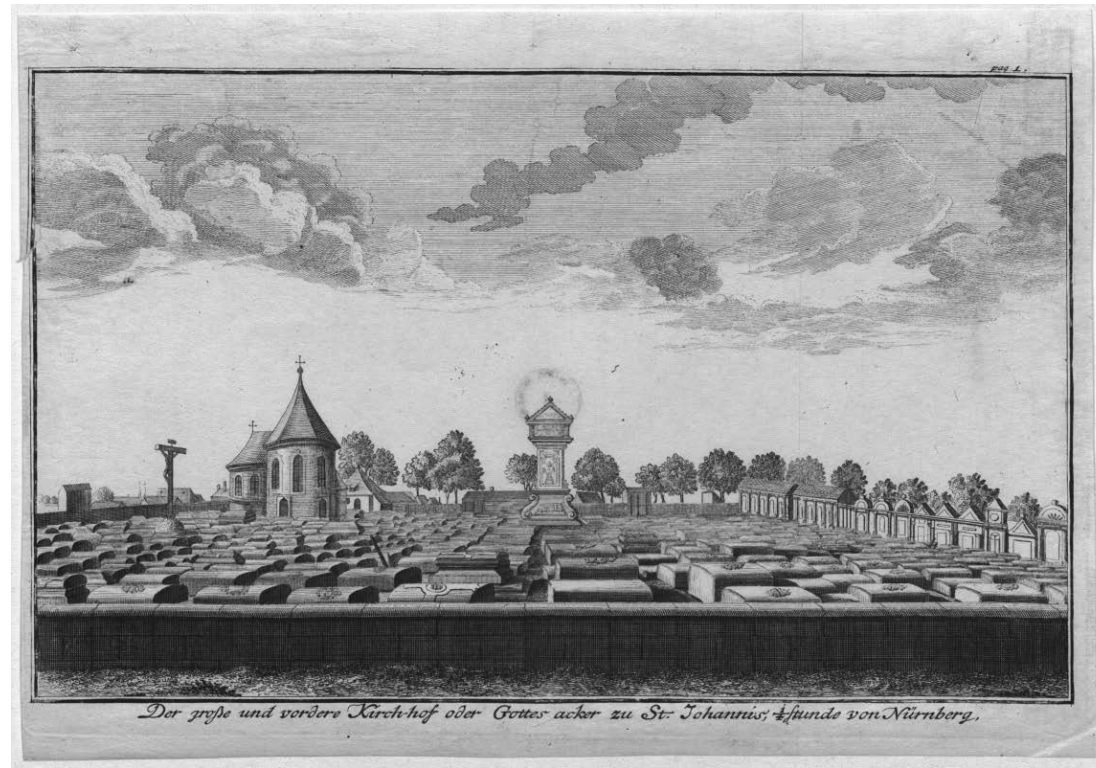

Fig. 17: Johann Alexander Boener (Engraver): St John's Cemetery (Wien, Österreichische Nationalbibliothek)

ventures, but even when the weather gets in the way of the stroller, there is a rainbow arcing above, symbolizing Nürnberg's harmonious relation to God. Dominion is shown through its success, in the stable order and in the prosperity ensured and made visible through artisan handwork and the movement of goods in regional and transregional trade. Security is generated by such internal stability; externally, it is demonstrated through unwavering attention to defensive potential; particularly in consideration of the inadequacy of the town's defensive equipment and its incapacity to man them with its own forces, the celebration of periodic military reviews and exercises was important.

\section{Stability: The power of securitization}

Unfortunately, it is impossible to fully explain the mechanisms that led to such a remarkable spate of image series depicting Nürnberg and its environs, which is impressive even in European comparison. Despite the broad preservation of the image series, their addressees and the circumstances of 
their reception are difficult to determine in detail. ${ }^{107}$ We can presume that the purchasers of the image series came primarily from the families whose country estates are depicted and from families of similar status in other imperial cities. For example, in the case of the Dutch landscape images and vedute, it is apparent that they served for self-affirmation and outward representation. ${ }^{108}$ Moreover, we can assume that city books and image series about other major European cities created a market that catered to a widespread interest in "descriptions." It is important to note that the pictures circulated in the same (augmented) social group that saw itself as the guardian of order in Nürnberg. This notion is supported by the way the images deal with the figures that populate them. The streets and environs of Nürnberg were peopled with the "common man," who goes about his business, whether as a handworker, merchant, a farmer going to market or a domestic, either male or female. People are presented in a broad view, or "seen from above." This perspective is especially compelling in one image, when during the 1649 Nürnberg peace festival, the Swedish ambassador arranged for the heraldic animals symbolizing his ruling house to spew out red and white wine from the first floor of the city hall. In the descriptions of the festival, the depiction of responses to this generosity occupies as much space as the heraldic and technical explanations. ${ }^{109}$ "It was a pleasure there to see / how the common people were attracted there," writes Sigmund von der Birken in 1652, communicating both the impressions of direct observers and the various moral and political interpretations of the event that had subsequently developed in Nürnberg. ${ }^{110}$ The images, published in part as handbills and in part to illustrate descriptions of the festival differ only in minor ways. They do highlight the distance between the distinguished observers of the scene - on the square and watching from the windows of the city hall - and the common people scuffling for the wine. There is reason to conclude that the illustrated broadsheets showing this event were intended for purchase by the same prominent

107 Bellingradt (2011) asserts the absence of any overview of journalism in the early modern era and has attempted to create one for the cities of Cologne, Hamburg, Leipzig, and Dresden. However, the images we have been exploring here are not examined in his work.

108 Leeflang 1997, pp. 53-115.

109 Von Birken 1649. The figure comes from this version. Regarding the event itself, see Laufhütte 1998.

110 Von Birken 1652, pp. 68f.: „Da ware ein Lust zu sehen / wie sich der Poebel hinzudraengete.“. 
class as we see depicted in the picture with coats, hats, and lace collars, keeping a safe distance from the Volk. ${ }^{111}$

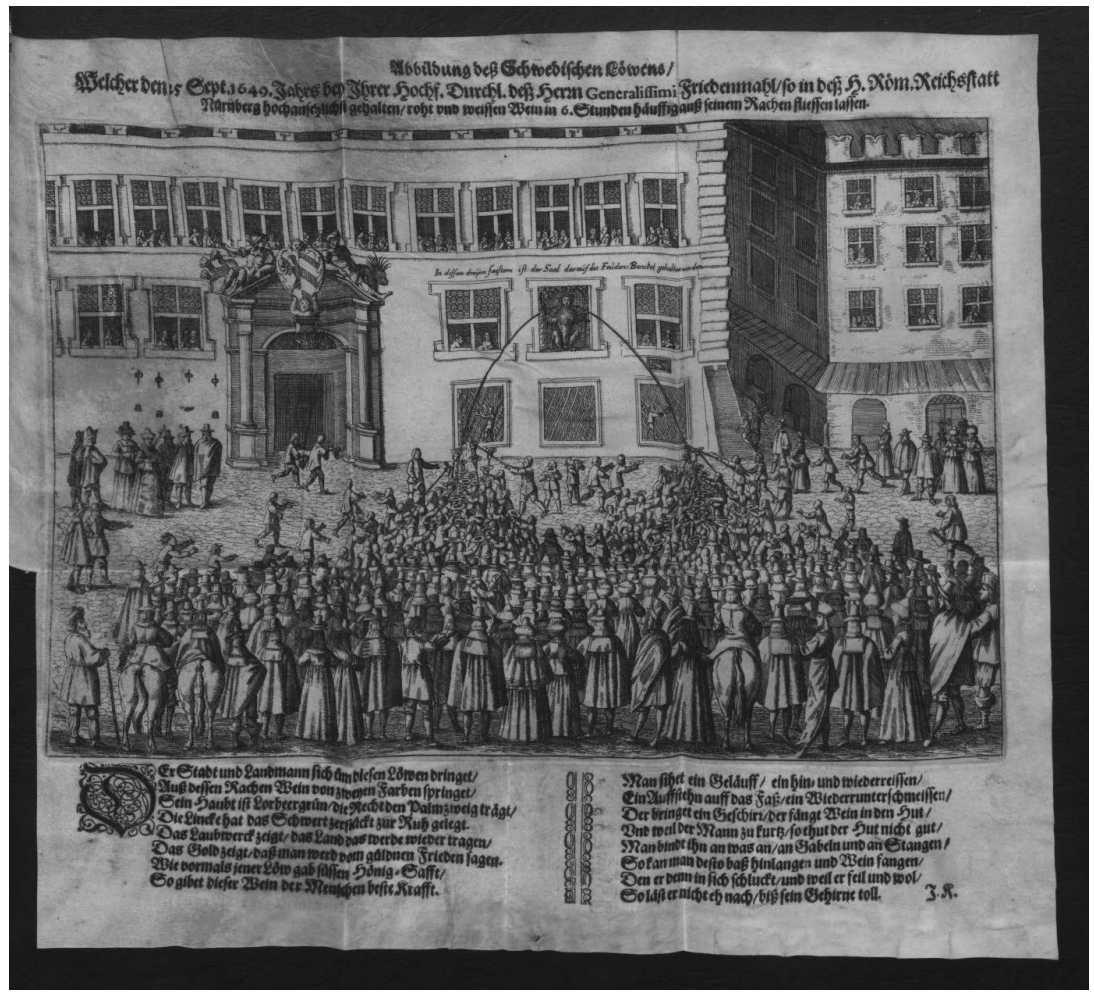

Fig. 18: The Swedish Lion spewing forth red and white wine, from: Sigmund von Birken (Text): Kurtze Beschreibung Deß Schwedischen Friedensmahls [Brief Description of the Swedish Peace Banquet], Nürnberg: Dümler 1649 (Coburg, Landesbibliothek).

Ruptures in this fabric of power relationships, the demarcation of a separate self-understanding of a social group, and pictorial representation of these ruptures and demarcations began to appear and gradually produced

111 Harms assumes that the flyers for the Peace Meal "represented cheap popular version(s) of the ambitious book edition (Harms 1980, nos. 323-328). He does not attempt a more extensive differentiation. 
signs of breakdown of the representative order, as travelers noted the unusual aspects of Nürnberg in European comparison as objects curiosity. Depending on the type of publication, they sometimes cloaked their observations in scathing wit and sharp criticism. The dress code continued to be binding on council-eligible families, who saw themselves as equal to the European aristocracy, even though the dress code made them laughable among the European aristocratic society. "These haughty Lords, swoln with Pride and vain of the Title they have assumed to themselves, together with their pointed Hats and bushy enormous Ruffs, that might serve for Umbrella's to two or Three Women, are more arrogant and inaccessible than the Nobles of Venice" was how Blainville described the Nürnberg elite in his travelogue, first published in English translation in London. ${ }^{112}$ Nicolai, for his part, came to the conclusion in 1783 that Nürnbergers lagged 150 years behind current standards in the design of their houses. ${ }^{113}$

Helmut Zedelmaier demonstrated gaps between literary presentation and social and political reality in the large collections of city descriptions and concluded that these gaps were partly the reflection of stable literary conventions. Once complete, "an 'ensemble' of literary tradition developed, which sealed up against reality, and followed its own laws. [...] Only Enlightenment concerns about pragmatic access to the present succeeded in destroying the static nature of the [literary!] images: then, the order of literary tradition was no longer available to them, but only the order of empirical reality."114

However, what may be undoubtedly true for the widely read compendia of city books is not necessarily applicable to the local text and image production. It falls short if one describes the inertial tendency expressed in actuality and in the images as being "sealed up" against reality. What is depicted in the images is a wished-for political and social reality, and all visual means are deployed to make this ideal image seem plausible. Indeed, it may be surprising that the themes set down since the city hall vedute of 1621 would continue to be disseminated through new editions of the image series by Graff, Boener, and Delsenbach through the end of the eighteenth century. And we can safely assume that these editions were published entirely free from any political interventions by the Council and

112 Blainville/Turnbull/Köhler 1764, Vol. 1.1, p. 230. Blainville was in Nürnberg in 1705. English edition 1767, Vol. 1, pp. 198-199.

113 Nicolai 1783-1796, Vol. 1, p. 205.

114 Zedelmaier 1987, p. 308. 
brought to market purely based on the publisher's good business interests. However, the fundamental function of these later editions remained the same as it was at the time of the first edition, perhaps even strengthened by the fact that the persons and activities shown in the images had become a part of history, while there had been little change in the architecture or the political, social and economic processes depicted. The consistent function was to portray as well as engender the stability of the societal and political order through the stability of visual appearances.

Thus, it is only possible to differentiate between the tasks of representing and creating security as aspects of securitization if the specific situational use of the images can be precisely determined as a means of communication. However, in the case of the broad continuity of the image production, this does not make sense. The communicative power of the prints resulted from their adaptability to different prevailing conventions of presentation, and, above all, their persistent presentation of variations of a few basic themes, thus enabling them to help strengthen civic order through their repeated reception and remembrance. For over 200 years, the vedute created a picture of Nürnberg where security was manifested in the day-to-day routines of the people depicted and a stable, unvarying presentation of the architectonic framework of an order undisturbed by small, day-to-day misadventures; at the same time, this order had to be and could be protected from latent threat. When the question is one of an external threat, such protection is articulated in the images; when the issue is potential internal conflict, it remains invisible and is not directly addressed. For instance, there never seem to be any beggars in the city - but beggars might be an indicator for the need for better regulation of order. By contrast, the security problem - that is, the threat from an external enemy - is permanently commemorated while the pictures continue to be produced and received. The vedute remind a wandering gaze everyday realities that were also experienced on the street; lacking sources, we cannot describe these realities empirically: the power of the architecture to steer day-today routines. The chain barriers divided the flow of traffic, traces of which remain in the roadways of the main streets; the old gate towers (White Tower, fig. 9) narrowed it once more inside the town after passing through the fortifications. The images consistently cast this feature of the architecture and contrivances in a positive light. The towers and walls, chain barriers and watchtowers are the community's own means of guaranteeing security. To this end, each house also has its own defenses to protect it against an enemy we will not try to specify in further detail here. Not 
quantitatively dominant, although unmistakably present, is the symbol of penal justice as guarantor of internal security, the gallows hill, which appears in every full view of the city on the eastern side. ${ }^{115}$

In conclusion, it makes sense to emphasize this aspect of persistence/ repetition for the presentation and perception of security themes, because it also makes clear that the mechanisms proposed by the Copenhagen School of Critical Security Studies are unsuitable for understanding the consistent communication of a security theme over an extended time. In Nürnberg, securitization did not take place as an orchestrated staging of the circumstances surrounding a security problem, nor was desecuritization the ultimate message of normal political activity. The subject and function of the images is not the "abrogation of normally applicable boundaries and limitations of political action through securitization,"116 but instead security being in force and remaining in force across many centuries, even while - as the vedute also show - it could be terminated at any time, to the detriment of the community. To the extent that these marketable vedute - tolerated and sometimes also sponsored by the Council depicted security architectures, arrangements, and routines and preserved the memory of a latent threat, they helped to create security. In this sense, they are a means for legitimizing council rule - through the representation of order as well as through pastoral, peaceful utopias and not through images of horror, which were exceedingly rare in Nürnberg. ${ }^{117}$ A condition for the efficacy of the images is an underlying consensus between the actors, between the Council, the producers of the pictures who were mostly in concurrence with it, and the inhabitants of the city. The series of vedute are thus an example of an image type capable of exercising an effect within a type of security power - the power of securitization. ${ }^{118}$ Their long persistence, generation of tradition and reinforcing effects to create a collective Nürnberg identity in the upper class, which is crystallized in their security routines, provides impressive proof that in long-term securitization processes, just as in dramatic event-driven securitizing moves, the players cannot avoid some degree of self-imposed confinement.

115 E.g. Wolgemut, Lautensack. see also the coach with curtained windows and the Jew (?), who is being taken to the city hall by a council servant in Lorenz Strauch.

116 Conze 2012, p. 459, characterizing the positions of the Copenhagen School.

117 On this problem area, see Härter 2010.

118 See Langenohl in this volume, section 3.2. 


\section{References}

“gantz verheeret!“. Magdeburg und der Dreißigjährige Krieg (1998). Halle (Saale): mdv, Mitteldeutscher Verlag.

Abelinus, Johann Philipp/Merian d.Ä., Matthaeus/Oraeus, Heinrich (1646): Theatrvm Evropaevm, oder außführliche vnd warhafftige Beschreibung aller vnd jeder denckwürdiger Geschichten, so sich hin und wieder in der Welt, fürnämlich aber in Europa, vnd Teutschlanden... zugetragen haben. Vol. 2, Frankfurt am Main: Matthaeus Merian.

Althaus, Thomas (2001): Es ist nichts unnatürlicher als der Frieden. Lebensform Krieg und Friedenskunst im 17. Jahrhundert. In: Klaus Garber (ed.): Erfahrung und Deutung von Krieg und Frieden. Religion - Geschlechter - Natur und Kultur. München: Wilhelm Fink Verlag, pp. 690-713.

Arnold, Klaus (2004): Die ,Norinberga' des Conrad Celtis - ihre Entstehung und Aufnahme in Nürnberg. In: Konrad Celtis und Nürnberg. (= Pirckheimer-Jahrbuch 19.) Wiesbaden: Harrassowitz, pp. 100-116.

Bach-Damaskinos, Ruth (2006): Johann Adam Delsenbach. Alt-Nürnberger Ansichten. Nürnberg: Hofmann Verlag.

Bätschmann, Oskar (1997): Ausstellungskünstler. Kult und Karriere im modernen Kunstsystem. Köln: DuMont.

Bellingradt, Daniel (2011): Flugpublizistik und Öffentlichkeit um 1700. Dynamiken, Akteure und Strukturen im urbanen Raum des Alten Reiches. Stuttgart: Franz Steiner Verlag.

Bendlage, Andrea (2003): Henkers Hetzbruder. Das Strafverfolgungspersonal der Reichsstadt Nürnberg im 15. und 16. Jahrhundert. Konstanz: UVK Verlagsgesellschaft.

Berns, Jörg Jochen (1993): Umrüstung der Mnemotechnik im Kontext von Reformation und Gutenbergs Erfindung. In: Jörg Jochen Berns/Wolfgang Neuber (eds.): Ars memorativa: zur kulturgeschichtlichen Bedeutung der Gedächtniskunst 1400-1750. Tübingen: Niemeyer, pp. 35-72.

Besing, Thomas (1999): Produktion und Publikum - Aspekte der Herstellung, Verbreitung und Rezeption Frühneuzeitlicher Stadtdarstellungen. In: Wolfgang Behringer/ Bernd Roeck (eds.): Das Bild der Stadt in der Neuzeit 1400-1800. München: C. H. Beck, pp. 94-100.

Beyme, Klaus von (1998): Die Kunst der Macht und die Gegenmacht der Kunst. Studien zum Spannungsverhältnis von Kunst und Politik. Frankfurt am Main: Suhrkamp.

Bigo, Didier (2002): Security and immigration: Toward a critique of the governmentality of unease. Alternatives: Global, Local, Political 27: 63-92.

Bildersturm in Osteuropa. Die Denkmäler der kommunistischen Ära im Umbruch. (1994). Deutsches Nationalkomitee von ICOMOS (ed.), München: Lipp. 
Birken, Sigmund von (1652): Die Fried-erfreuete Teutonie. Eine Geschichtschrifft von dem Teutschen Friedensvergleich, was bey Abhandlung dessen, in des H. Röm. Reichs Stadt Nürnberg, nachdem selbiger von Osnabrügg dahin gereiset, denkwürdiges vorgelauffen, mit allerhand Staats- und Lebenslehren, Dichtereyen, auch darein gehörigen Kupffern gezieret, in vier Bücher abgetheilet. Nürnberg: Jeremias Dümler 1652 [VD17 23:251510R].

Birken, Sigmund von (1649): Kurtze Beschreibung Deß Schwedischen Friedensmahls, gehalten in Nürnberg den 25. Herbstmonats Anno 1649. Nürnberg: Jeremias Dümler [VD17 14:001030F].

Blainville, J. de/Turnbull, George/ Köhler, Johann Tobias (1764): Des Herrn von Blainville ehemaligen Gesandtschaftssekretäres der Generalstaaten der vereinigten Niederlande an dem Spanischen Hofe Reisebeschreibung durch Holland, Oberdeutschland und die Schweiz, besonders aber durch Italien. Lemgo 1764.

Blainville, J. de/Turnbull, George/ Köhler, Johann Tobias (1767): Travels through Holland, Germany, Switzerland and Italy. Containing a particular description of the antient and present state of those countries. London: J. Johnson and B. Davenport.

Böschenstein, Renate (2001): Arkadien - Ein Friedensreich? In: Klaus Garber (ed.): Erfahrung und Deutung von Krieg und Frieden. Religion - Geschlechter - Natur und Kultur. München: Wilhelm Fink Verlag, pp. 667-689.

Braun, Georg/Hogenberg, Franz (1582): Contrafactur und Beschreibung von den vornehmbsten Stetten der Welt, Liber tertius. Köln: Franz Hogenberg.

Bredekamp, Horst (2010): Theorie des Bildakts. Frankfurter Adorno-Vorlesungen 2007. Berlin: Suhrkamp Verlag. 2010.

Burckhardt, Johannes (1998): Auf dem Wege zu einer Bildkultur des Staatensystems. Der Westfälische Frieden und die Druckmedien. In: Heinz Duchhardt (ed.): Der Westfälische Friede. Diplomatie, politische Zäsur, kulturelles Umfeld, Rezeptionsgeschichte. München: Oldenbourg, pp. 81-114.

Bürger, Peter (1974): Theorie der Avantgarde. Berlin: Suhrkamp Verlag.

Busch, Werner (ed.) (1987): Funkkolleg Kunst. Eine Geschichte der Kunst im Wandel ihrer Funktionen. München: Piper.

Buzan, Barry/Wæver, Ole/de Wilde, Jaap (1998): Security: A New Framework for Analysis. Boulder, CO: Lynne Rienner.

Celtis, Conrad (1921): Norinberga. De situ, moribus et institutis Norimbergae libellus. Conrad Celtis und sein Buch über Nürnberg. Ed. by Albert Werminghoff. Freiburg: J. Boltze.

Cilleßen, Wolfgang (ed.) (1997): Krieg der Bilder. Druckgraphik als Medium politischer Auseinandersetzung im Europa des Absolutismus. Berlin: Deutsches Historisches Museum.

Cilleßen, Wolfgang/ Reichardt, Rolf (eds.) (2010): Revolution und Gegenrevolution in der europäischen Bildpublizistik 1789-1889. Hildesheim: Olms.

Cochlaeus, Johannes (1960): Brevis Germaniae descriptio (1512). Ed. and transl. by Karl Langosch. Darmstadt: Wissenschaftliche Buchgesellschaft. 
Conze, Eckart (2012): Securitization. Gegenwartsdiagnose oder historischer Analyseansatz? Geschichte und Gesellschaft. Zeitschrift für historische Sozialwissenschaft 38: 453- 467.

Der Stat Nürnberg verneute Reformation (1564). Nürnberg: Valentin Geisler.

Diefenbacher, Jörg (2002): Die Schwalbacher Reise, gezeichnet von Anton Mirou in Kupfer gestochen von Matthäus Merian d.Ä., 1620. Mannheim: Selbstverlag.

Donaubauer, Stephan (1899): Gustav Adolf und Wallenstein vor Nürnberg im Sommer des Jahres 1632. Mitteilungen des Vereins für Geschichte der Stadt Nürnberg 13: 53-78.

Doosry, Yasmin (2014): „Also muss es von oben herab verstanden werden“. Topographische Vogelschauansichten. In: Yasmin Doosry (ed.): Von oben gesehen. Die Vogelperspektive. Nürnberg: Germanisches Nationalmuseum, pp. 97-125.

Düriegl, Günther (1980): Die Rundansicht des Niklas Meldemann zur ersten Belagerung Wiens durch die Türken im Jahre 1529. Interpretation und Deutung. Wien: Jugend und Volk.

Emblemata Politica. In aula magna Curiae Noribergensis depicta, quae sacra Virtutum suggerunt Monita Prudenter administrandi Fortiterque defendendi Rempublicam (1617, 1640), Nürnberg: Peter Isselburg/Wolff Endter.

Mende, Matthias (1979): Das Alte Nürnberger Rathaus. Baugeschichte und Ausstattung des großen Saales und der Ratsstube. Nürnberg: Stadtgeschichtliche Museen.

Erben, Dietrich (2003/2004): Angst und Architektur. Zur Begründung der Nützlichkeit des Bauens. Hephaistos. New approaches in Classical Archaeology and related fields 21/22: 29-51.

Eser, Thomas (2014): Über-Blick. Die kartographische Perspektive. In: Yasmin Doosry (ed.): Von oben gesehen. Die Vogelperspektive. Nürnberg: Germanisches Nationalmuseum.

Falk, Tilman (ed.) (1975): Hollstein's German engravings, etchings and woodcuts. 1400-1700. Vol. X, Blaricum: van Gendt.

Fink, Gerhard (2000): Konrad Celtis. 'Norimberga'. Ein Büchlein über Ursprung, Lage, Einrichtungen und Gesittung Nürnbergs. Nürnberg: Verlag Nürnberger Presse.

Fischer, Dieter/Maué, Hermann (2014): Medaillen und Schaumünzen auf Ereignisse in der Reichsstadt Nürnberg 1521-1806. Nürnberg: Verlag des Germanischen Nationalmuseums.

Fleckner, Uwe (ed.) (2011): Der Sturm der Bilder. Zerstörte und zerstörende Kunst von der Antike bis in die Gegenwart. Berlin: Akademie Verlag.

Fleischmann, Peter (1991): Der Nürnberger Zeichner, Baumeister und Kartograph Hans Bien (1591-1632). Ausstellungskatalog Staatsarchiv Nürnberg. München: Generaldirektion der Staatlichen Archive Bayerns, pp. 118-137.

Fleischmann, Peter (2008): Rat und Patriziat in Nürnberg. Die Herrschaft der Ratsgeschlechter vom 13. bis zum 18. Jahrhundert, Bd. 1. Der kleinere Rat. Nürnberg: Verein für Geschichte der Stadt Nürnberg.

Freedberg, David (1991): The Power of Images. Studies in the History and Theory of Response. Chicago: University of Chicago Press. 
Gamboni, Dario (1998): Zerstörte Kunst. Bildersturm und Vandalismus im 20. Jahrhundert. Köln: DuMont.

Garber, Klaus (1995): Pastorales Dichten des Pegnesischen Blumenordens in der Sozietätsbewegung des 17. Jahrhunderts. Ein Konspekt in 13 Thesen. In: John Roger Paas (ed.): Der Franken Rom. Nürnbergs Blütezeit in der zweiten Hälfte des 17. Jahrhunderts. Wiesbaden: Harrassowitz Verlag, pp. 146-154.

Garber, Klaus (2009): Arkadien. Ein Wunschbild der europäischen Literatur. Paderborn, München: Wilhelm Fink Verlag.

Gibson, Walter S. (2000): Pleasant Places: The Rustic Landscape from Bruegel to Ruisdael. Berkeley: University of California Press.

Giersch, Robert/Schlunk, Andreas/Haller, Bertold von (2007): Burgen und Herrensitze in der Nürnberger Landschaft (http://www.herrensitze.com/st-johannis-i.html). Neuhaus an der Pegnitz: Altnürnberger Landschaft.

Goldstein, Robert Justin (2012): Out of Sight: Political Censorship of the Visual Arts in Nineteenth-century France. New Haven: Yale University Press.

Groebner, Valentin (1994): Ratsinteressen, Familieninteressen. Patrizische Konflikte in Nürnberg um 1500. In: Klaus Schreiner (ed.): Stadtregiment und Bürgerfreiheit. Handlungsspielräume in deutschen und italienischen Städten des späten Mittelalters und der frühen Neuzeit. Göttingen: Vandenhoeck und Ruprecht, pp. 279-308.

Gundling, Nicolaus Hieronymus (1706): Des heil. Römischen Reichs freye Stadt Nürnberg, Nürnberg: n.p.

Guzzini, Stefano (2011): Securitization as a causal mechanism. In: Security Dialogue 42: 329-341.

Hampe, Theodor (1904): Nürnberger Ratsverlässe über Kunst und Künstler im Zeitalter der Spätgotik und Renaissance, 1474-1618. Vol. 1. Nürnberg: Karl Graeser \& Kie.

Hampe, Theodor (1918): Johann Philipp Andreae und das Medaillen-Pasquill auf den Nürnberger Rat vom Jahre 1731. Mitteilungen des Vereins für Geschichte der Stadt Nürnberg 22: 244-279.

Hansen, Lene (2011): Theorizing the image for Security Studies: Visual securitization and the Muhammad Cartoon Crisis. European Journal of International Relations 17(1): 51-74.

Harms, Wolfgang (ed.) (1980): Deutsche illustrierte Flugblätter des 16. und 17. Jahrhunderts. Die Sammlung der Herzog-August-Bibliothek in Wolfenbüttel: Teil 2: Historica. Tübingen: Niemeyer Verlag.

Harms, Wolfgang (ed.) (1983): Illustrierte Flugblätter aus den Jahrhunderten der Reformation und der Glaubenskämpfe. Kunstsammlung der Veste Coburg. Coburg: Kunstsammlungen der Veste Coburg.

Harms, Wolfgang /Schilling, Michael (2008): Das illustrierte Flugblatt der frühen Neuzeit. Traditionen - Wirkungen - Kontexte. Stuttgart: Hirzel Verlag.

Harsdörffer, Georg Philipp/Birken, Sigmund von/Klaj, Johann (1644): Pegnesisches Schäfergedicht, 1644-1645. Ed. by Klaus Garber. Reprint. Tübingen: Niemeyer Verlag. 
Härter, Karl (ed.) (2010): Repräsentationen von Kriminalität und öffentlicher Sicherheit. Bilder, Vorstellungen und Diskurse vom 16. bis zum 20. Jahrhundert. Frankfurt a.M.: Vittorio Klostermann.

Haskell, Francis (1980): Patrons and Painters. A Study in the Relations between Italian Art and Society in the Age of Baroque. New Haven: Yale University Press.

Hattendorff, Claudia (2012): Napoleon I. und die Bilder. System und Umriss bildgewordener Politik und politischen Bildgebrauchs. Petersberg: Michael Imhof Verlag.

Hebel, Udo J./Wagner, Christoph (2011): Pictorial Cultures and Political Iconographies: Approaches, Perspectives, Case Studies from Europe and America. Berlin: de Gruyter.

Hoffmann-Rehnitz, Philip R. (2016): Zur Unwahrscheinlichkeit der Krise in der Frühen Neuzeit. Niedergang, Krise und gesellschaftliche Selbstbeschreibung in innerstädtischen Auseinandersetzungen nach dem Dreißigjährigen Krieg am Beispiel Lübecks. In: Rudolf Schlögl/Philip R. Hoffmann-Rehnitz/Eva Wiebel (eds.): Die Krise in der Frühen Neuzeit. Göttingen: Vandenhoek \& Ruprecht, pp. 169-208.

Hofmann, Hanns Hubert (1965): Nobiles Norimbergenses. Beobachtungen zur Struktur der reichsstädtischen Oberschicht. Zeitschrift für bayerische Landesgeschichte 28: 114-150.

Huntebrinker, Jan Willem (2009): Herrschaftswissen im Spannungsfeld zwischen Mitteilung und Geheimhaltung: Überlegungen zur obrigkeitlichen Informationspolitik des Nürnberger Rats im Kontext der carolinischen Regimentsreform 1548/49. In: Bulst, Neithard (ed.): Politik und Kommunikation. Zur Geschichte des Politischen in der Vormoderne. Frankfurt am Main: Campus Verlag, pp. 69-94.

Imhof, G. von (1880): Hans Sebald Lautensacks Ansichten von Nürnberg. Mitteilungen des Vereins für Geschichte der Stadt Nürnberg 2: 164-186.

Israel, Uwe (2012): Masse und Stadt. Die Bewältigung großer Menschenmengen im Mittelalter am Beispiel von Nürnberg. Concilium medii aevi 15: 151-183 (http:// cma.gbv.de,cma,015,2012,a,05.pdf).

Jachmann, Julian (2008): Die Kunst des Augsburger Rates 1588-1631. Kommunale Räume als Medium von Herrschaft und Erinnerung. München. Berlin: Deutscher Kunstverlag.

Jachmann. Julian (2013): Reichsstädtische Kunstpolitik in Augsburg und Nürnberg. Komplementäre Strategien im Umgang mit symbolischem Kapital. In: Thomas Schauerte et al. (eds.): Dürer und das Nürnberger Rathaus. Aspekte von Ikonographie, Verlust und Rekonstruktion. Petersberg: Michael Imhof Verlag, pp. 90-109.

Johnson, Matthew (2006): Houses, power, and every day life in Early Modern England. In: Joseph Maran/Carsten Juwig/Hermann Schwengel/Ulrich Thaler (eds.): Constructing Power: Architecture, Ideology, and Social Practice. Münster, Berlin: Lit, pp. 285-298.

Kampmann, Christoph/Krems, Eva/Krause, Katharina/Tischer, Anuschka (eds.) (2012): Neue Modelle im alten Europa. Traditionsbruch und Innovation als Herausforderung in der Frühen Neuzeit. Köln: Böhlau. 
Kemp, Wolfgang (1993): Text/Kontext, Grenze/Austausch. Zugleich ein Versuch über Nancy zur Zeit Stanislas Leszczynskis. In: Thomas W. Gaehtgens (ed.): Künstlerischer Austausch, Akten des XXVIII. Internationalen Kongresses für Kunstgeschichte, vol 2. Berlin: Akademie Verlag, pp. 653-664.

Laufhütte, Hartmut (1998): Das Friedensfest in Nürnberg 1650. In: 1648: Krieg und Frieden in Europa, Textband 2, Kunst und Kultur. Münster: Westfälisches Landesmuseum für Kunst und Kulturgeschichte, pp. 347-357.

Lauterbach, Iris (2011): Johann Christoph Volkamers Hesperidenwerk. In: Die Frucht der Verheißung: Zitrusfrüchte in Kunst und Kultur. Nürnberg: Verlag des Germanischen Nationalmuseums, pp. 237-263.

Leeflang, Huigen (1997): Dutch Landscape: the urban view. Haarlem and its environs in literature and art, 15th.-17th. Century. Nederlands kunsthistorisch jaarboek 48: 53-115.

Locher, Hubert/Markantonatos, Adriana (eds.) (2013): Reinhart Koselleck und die politische Ikonologie. Berlin: Deutscher Kunstverlag.

Mahn, Hannshubert (1927): Lorenz und Georg Strauch. Beiträge zur Kunstgeschichte Nürnbergs im 16. und 17. Jahrhundert. Reutlingen: Gryphius.

Maisak, Petra (1981): Arkadien. Genese und Typologie einer idyllischen Wunschwelt, Frankfurt am Main: Lang.

Mallinckrodt, Rebekka von (2006): Unsichtbare Macht - Repräsentative Machtlosigkeit? Ein Vergleich politischer Einflussmöglichkeiten und architektonischer Repräsentation frühneuzeitlicher Bruderschaften in Venedig und Köln. In: Christian Hochmuth/Susanne Rau (eds.): Machträume der frühneuzeitlichen Stadt. Konstanz: UKV, pp. 333-354.

Martz, Jochen (2008): Johann Christoph Volkamer und die Entwicklung der Zitruskultur in Nürnbergs Gärten. In: Lust und Lieb hat mich beweget. Nürnbergs Gartenkultur. Zirndorf: Bollmann, pp. 35-40.

McDonald, Matt (2008): Securitization and the Construction of Security. European Journal of International Relations 14: 563-587.

Meldemann, Nikolaus (1530): Ein kurtzer bericht vber die recht warhafftig Contrafactur, Türckischer belegerung der Stat Wien, wie dieselbig anzusehen vnd zuuersteen sey. Nürnberg: Hieronymus Andreae, Nikolaus Meldemann.

Mende, Matthias (1999): Nürnberg. In: Wolfgang Behringer/Bernd Roeck (eds.): Das Bild der Stadt in der Neuzeit 1400-1800. München: C. H. Beck, pp. 334-339.

Merian, Matthäus d.Ä. (ed.) (1648):Topographia Franconiae. Frankfurt: Matthäus Merian.

Meyer, Carla (2009): Die Stadt als Thema. Nürnbergs Entdeckung in Texten um 1500. Ostfildern: Jan Thorbecke Verlag.

Misson, François Maximilien (1701): Reisen aus Holland durch Deutschland in Italien. Leipzig: Fritsch.

Mühleisen, Hans Otto (2005): Kunst und Macht im politischen Prozess. Prolegomena einer Theorie politischer Bildlichkeit. In: Wilhelm Hofmann/Hans Otto Mühleisen (eds.): Kunst und Macht. Politik im Medium der bildenden Kunst. Münster: Lit Verlag, pp. 1-18. 
Müller, Christian Gottlieb (1791): Verzeichnis von nürnbergischen topographisch-historischen Kupferstichen und Holzschnitten. Nürnberg: Bieling.

Münkler, Herfried (1995): Die Visibilität der Macht und die Strategien der Machtvisualisierung. In: Gerhard Göhler (ed.): Macht der Öffentlichkeit - Öffentlichkeit der Macht. Baden-Baden: Nomos Verlags-Gesellschaft, pp. 213-230.

Münster, Sebastian (1550): Cosmographiae uniuersalis Lib. VI. in quibus, iuxta certioris fidei scriptorum traditionem describuntur, Omniu[m] habitabilis orbis partiu[m] situs... Omnium gentiu[m] mores, leges, religio, res gestae, mutationes: Item regum \& principum genealogiae. Basel: Heinrich Petri.

Nicolai, Friedrich (1783-1786): Beschreibung einer Reise durch Deutschland und die Schweiz, im Jahre 1781. Nebst Bemerkungen über Gelehrsamkeit, Industrie, Religion und Sitten. Vol. 1, Berlin/Stettin: Selbstverlag.

Nuti. Lucia (1994): The perspective plan in the sixteenth century. The invention of a representational language. Art bulletin 76: 105-128.

Paul, Gerhard (2013): BilderMACHT. Studien zur "Visual History" des 20. und 21. Jahrhunderts. Göttingen: Wallstein Verlag.

Pennington, Richard (1982): A Descriptive Catalogue of the Etched Work of Wenceslaus Hollar 1607-1677. Cambridge: Cambridge University Press.

Pfeiffer, Gerhard (ed.) (1971): Nürnberg - Geschichte einer europäischen Stadt. München: C. H. Beck.

Philipp, Marion (2011): Ehrenpforten für Kaiser Karl V. Festdekoration als Medium politischer Kommunikation. Münster: Lit Verlag.

Pilz, Kurt (1952): Nürnberg und die Niederlande. Mitteilungen des Vereins für Geschichte der Stadt Nürnberg 43: 1-153.

Pilz, Kurt (1984): St. Johannis und St. Rochus in Nürnberg. Nürnberg: Hans Carl Verlag.

Popitz, Heinrich (1992): Phänomene der Macht. 2., stark erw. Aufl. Tübingen: Mohr Siebeck.

Prange, Peter (1997): Salomon Kleiner und die Kunst des Architekturprospekts. Augsburg: Wissner Verlag.

Riegg, Ernst (2004): Eigenwille und Pragmatismus. Der Konflikt um die Norma Doctrinae in der Reichsstadt Nürnberg. In: Rudolf Schlögl (ed.): Interaktion und Herrschaft. Die Politik der frühneuzeitlichen Stadt. Konstanz: UVK Verlags-Gesellschaft, pp. 237-267.

Rogge, Jörg (2004): Kommunikation, Herrschaft und politische Kultur. Zur Praxis der öffentlichen Inszenzierung und Darstellung von Ratsherrschaft in Städten des deutschen Reiches um 1500. In: Rudolf Schlögl (ed.): Interaktion und Herrschaft - Die Politik der frühneuzeitlichen Stadt. Konstanz: UVK Verlags-Gesellschaft.

Rutz, Andreas (2014): Territorialpolitik mit Karten. Der Streit um die Landeshoheit zwischen Brandenburg-Ansbach und Nürnberg im 18. Jahrhundert. Zeitschrift für bayerische Landesgeschichte 77: 935-961.

Schäfer, Karl (1898): Des Hieronymus Braun Prospect der Stadt Nürnberg vom Jahre 1606 und seine Vorläufer. Mitteilungen des Vereins für Geschichte der Stadt Nürnberg 12: 3-84. 
Schaffer, Reinhold (1934): Das Pellerhaus in Nürnberg. Nürnberg: Ulrich Verlag.

Schauerte, Thomas (ed.) (2001): Die Ehrenpforte für Kaiser Maximilian I. Dürer und Altdorfer im Dienst des Herrschers. München: Deutscher Kunstverlag.

Schauerte, Thomas (ed.) (2013): Dürer und das Nürnberger Rathaus. Aspekte von Ikonographie, Verlust und Rekonstruktion. Petersberg: Michael Imhof Verlag.

Schenk, Gerrit J. (2010): „Human Security“ in the Renaissance? Securitas, Infrastructure, Collective Goods and Natural Hazards in Tuscany and the Upper Rhine Valley. In: Cornel Zwierlein u. a. (ed.): The Production of Human Security in Premodern and Contemporary History. Historical Social Research 35: 213-237.

Scheurl, Christoph (1874): Christoph Scheurl's Epistel über die Verfassung der Reichsstadt Nürnberg. 1516. In: Die Chroniken der fränkischen Städte. Nürnberg, Vol. 5. Leipzig: S. Hirzel, pp. 781-804.

Scheurl, Siegfried von (1999): Näher am Original? Zur Verfassung der Reichsstadt Nürnberg 1516. Mitteilungen des Vereins für Geschichte der Stadt Nürnberg 86: 21-46.

Schiermeier, Franz (ed.) (2006): Stadtatlas Nürnberg. Karten und Modelle von 1492 bis heute, München: Selbstverlag.

Schilling, Michael (1990): Bildpublizistik der frühen Neuzeit. Aufgaben und Leistungen des illustrierten Flugblatts in Deutschland bis um 1700. Tübingen: Niemeyer Verlag.

Schleif, Corine (1990): Donatio et memoria. Stifter, Stiftungen und Motivationen an Beispielen aus der Lorenzkirche in Nürnberg. München: Deutscher Kunstverlag.

Schlögl, Rudolf (2014): Anwesende und Abwesende: Grundriss für eine Gesellschaftsgeschichte der Frühen Neuzeit. Konstanz: Konstanz University Press.

Schmidt, Dagmar (2003): Der Freskenzyklus von Ambrogio Lorenzetti über die gute und die schlechte Regierung. Eine danteske Vision im Palazzo Pubblico von Siena. Diss. St. Gallen 2003: http://www.unisg.ch/www/edis.nsf/wwwDisplayIdentifier/26 56/\$FILE/dis2656.pdf.

Schmidt, Anja (2000): Augsburger Ansichten. Die Darstellung der Stadt in der Druckgraphik des 15. bis 18. Jahrhunderts. Augsburg: Wissner Verlag.

Schnadenberger, Eva (2016): „Die böse welt mit ihrer Sünd“. Zeitdiagnose in Liedflugblättern über Wunderzeichen des 17. Jahrhunderts. In: Rudolf Schlög1/Philip R. Hoffmann-Rehnitz/Eva Wiebel (eds.): Die Krise in der Frühen Neuzeit. Göttingen: Vandenhoeck \& Ruprecht, pp. 55-84.

Schnellbögl, Fritz (1996): Dokumente zur Nürnberger Kartographie. Nürnberg: Stadtbibliothek.

Schröder, Klaus Albrecht /Sternath, Maria Luise (eds.) (2003): Albrecht Dürer. Ostfilderen: Hatje Cantz.

Schwemmer, Wilhelm (ed.) (1981): Die Reichsstadt Nürnberg und ihr Umland um 1700. Kupferstiche. Johann Alexander Boener. Nürnberg: Korn und Berg.

Skinner, Quentin (1999): Ambrogio Lorenzetti's Buon Governo Frescoes: Two old Questions, Two new Answers. Journal of the Warburg and Courtauld Institutes 62: $1-28$. 
Smith, Jeffrey Chipps (2008): Imaging and imagining Nuremberg. In: Arthur Groos/ Hans-Jochen Schiewer/ Markus Stock (eds.): Topographies of the Early Modern City. Göttingen: V \& R Unipress, pp. 17-42.

Sporhan-Krempel, Lore (1968): Nürnberg als Nachrichtenzentrum zwischen 1400 und 1700. Nürnberg: Verein für Geschichte der Stadt Nürnberg.

Sporhan-Krempel, Lore/Wohnhaas, Theodor (1967): Ein neuer Fund zu Merians Topographia Franconiae. Archiv für die Geschichte des Buchwesens 55: 82-88.

Stiegler, Bernd. Review, H-Soz-u-Kult, H-Net Reviews. November, 2013. URL: http:// www.h-net.org/reviews/showrev.php?id=40673.

Suchtelen, Ariane van/Whelock Jr., Arthur K. (2009): Malerische Winkel - weite Horizonte. Holländische Stadtansichten des Goldenen Zeitalters von Vermeer bis Jan Steen. Stuttgart: Belser Verlag.

Tacke, Andreas (2001): ,Der Maler Ordnung und Gebräuch in Nürnberg‘. Die Nürnberger Maler(zunft)bücher ergänzt durch weitere Quellen, Genealogien und Viten des 16., 17. und 18. Jahrhunderts. München/Berlin: Deutscher Kunstverlag.

Timann, Ursula (1987): Der Rundprospekt der Nürnberger Landwehr von 1577. Anzeiger des Germanischen Nationalmuseums: 195-204.

Timann, Ursula (1993): Untersuchungen zu Nürnberger Holzschnitt und Briefmalerei in der ersten Hälfte des 16. Jahrhunderts mit besonderer Berücksichtigung von Hans Guldemund und Niclas Meldemann Münster: Lit Verlag.

Tipton, Susan (1996): Res publica bene ordinata. Regentenspiegel und Bilder vom guten Regiment. Rathausdekorationen in der Frühen Neuzeit. Hildesheim: Olms.

Trechsel, Johann Martin (1735): Verneuertes Gedächtnis des Nürnbergischen JohannisKirch-Hofs, Leipzig. Franckfurt/Leipzig: Adam Jonathan Felßeckers Erben.

Van Camp, An (2013): Jan Brueghel the Younger and the Nuremberg drawings. Delineavit et Sculpsit 36: 22-43.

Volkamer, Johann Christoph (1708): Nürnbergische Hesperides. Ed. by Harri Günther. Reprint Leipzig 1987. Nürnberg: Johann Andreas Endter Erben.

Völkel, Michaela (2001): Das Bild vom Schloss. Darstellung und Selbstdarstellung deutscher Höfe in Architekturstichserien 1600-1800. Berlin/München: Deutscher Kunstverlag.

Warncke, Carsten-Peter (2013): Dürers größtes Werk. Zur Geschichte und Ikonologie der Ausmalung des großen Nürnberger Rathaussaales. Ein Stiefkind der Forschung. In: Thomas Schauerte (et.al.) (ed.): Dürer und das Nürnberger Rathaus. Aspekte von Ikonographie, Verlust und Rekonstruktion. Petersberg: Michael Imhof Verlag, pp. 30-50.

Warnke, Martin, ed. (1984): Politische Architektur in Europa vom Mittelalter bis heute. Repräsentation und Gemeinschaft. Köln: Dumont.

Warnke, Martin (1996): Hofkünstler. Zur Vorgeschichte des modernen Künstlers. Köln: DuMont.

Willax, Franz (1979): Das Verteidigungswesen Nürnbergs im 17. und 18. Jahrhundert. Mitteilungen des Vereins für Geschichte der Stadt Nürnberg 66: 192-247. 
Willax, Franz (1991): „Gefährliche Patrioten und schädliche Leuth“. Antischwedischer Widerstand in Nürnberg 1631-1635. Mitteilungen des Vereins für Geschichte der Stadt Nürnberg 78: 123-173.

Williams, Michael C. (2003): Words, images, enemies: Securitization and international politics. International Studies Quarterly 47(4): 511-531.

Wimmer, Clemens Alexander (2011): Funktion und Bedeutung von Volkamers Zitrusbuch. In: Nürnbergische Hesperiden und Orangeriekultur in Franken. Petersberg: Michael Imhof Verlag, pp. 34-45.

Wüthrich, Lucas Heinrich (1993): Das druckgraphische Werk von Matthaeus Merian d. Ae., Vol. 3. Die großen Buchpublikationen. Hamburg: Hoffmann und Campe.

Zedelmaier, Helmut (1987): Stadtbeschreibung als literarische Tradition: Die fränkischen Reichsstädte in der kosmographisch-geographischen Literatur der frühen Neuzeit. In: Rainer A. Müller (ed.): Reichsstädte in Franken. Wirtschaft, Gesellschaft und Kultur. München: Haus der Bayerischen Geschichte, pp. 298-311.

Zimmermann, Walter (1930): Entwicklung des Nürnberger „Friedens- und Kriegskuriers“ („Nürnberger Kurier") von seinen ersten Anfängen bis zum Übergang an den „Fränkischen Kurier“" 1663-1865. Nürnberg: W. Tümmel. 
